\title{
SAVANNA RESPONSES TO FERAL BUFFALO IN KAKADU NATIONAL PARK, AUSTRALIA
}

\author{
Aaron M. Petty, ${ }^{1,2,6}$ Patricia A. Werner,${ }^{3,4,5}$ Caroline E. R. Lehmann,,${ }^{5}$ Jan E. Riley, ${ }^{4,5}$ Daniel S. Banfai, ${ }^{5}$ \\ AND Louis P. ElliotT ${ }^{4,5}$ \\ ${ }^{1}$ Department of Environmental Science and Policy, University of California, Davis, California 95616 USA \\ ${ }^{2}$ Tropical Savannas Cooperative Research Centre, Charles Darwin University, Darwin, NT 0909 Australia \\ ${ }^{3}$ The Fenner School of Environment and Society, Australian National University, Canberra, ACT 0200, Australia \\ ${ }^{4}$ Faculty of Education, Health and Science. Charles Darwin University, Darwin, NT 0909, Australia \\ ${ }^{5}$ School for Environmental Research, Charles Darwin University. Darwin, NT 0909, Australia
}

\begin{abstract}
Savannas are the major biome of tropical regions, spanning 30\% of the Earth's land surface. Tree: grass ratios of savannas are inherently unstable and can be shifted easily by changes in fire, grazing, or climate. We synthesize the history and ecological impacts of the rapid expansion and eradication of an exotic large herbivore, the Asian water buffalo (Bubalus bubalus), on the mesic savannas of Kakadu National Park (KNP), a World Heritage Park located within the Alligator Rivers Region (ARR) of monsoonal north Australia. The study inverts the experience of the Serengeti savannas where grazing herds rapidly declined due to a rinderpest epidemic and then recovered upon disease control.

Buffalo entered the ARR by the 1880s, but densities were low until the late 1950s when populations rapidly grew to carrying capacity within a decade. In the 1980s, numbers declined precipitously due to an eradication program. We show evidence that the rapid population expansion and sudden removal of this exotic herbivore created two ecological cascades by altering ground cover abundance and composition, which in turn affected competitive regimes and fuel loads with possible further, long-term effects due to changes in fire regimes. Overall, ecological impacts varied across a north-south gradient in KNP that corresponded to the interacting factors of precipitation, landform, and vegetation type but was also contingent upon the history of buffalo harvest. Floodplains showed the greatest degree of impact during the period of rapid buffalo expansion, but after buffalo removal, they largely reverted to their prior state. Conversely, the woodlands experienced less visible impact during the first cascade. However, in areas of low buffalo harvest and severe impact, there was little recruitment of juvenile trees into the canopy due to the indirect effects of grazing and high frequency of prescribed fires once buffalo were removed. Rain forests were clearly heavily impacted during the first cascade, but the long term consequences of buffalo increase and removal remain unclear. Due to hysteresis effects, the simple removal of an exotic herbivore was not sufficient to return savanna systems to their previous state.
\end{abstract}

Key words: Asian water buffalo; Bubalus bubalus; ecological cascades; grazing-fire interactions; historical ecology; hysteresis; invasive species; northern Australia; tropical savannas.

\section{INTRODUCTION}

Savannas cover almost a third of the world's land surface: over $50 \%$ the area of Africa, $50 \%$ of tropical Australia, $45 \%$ of South America, and about $10 \%$ of India and Southeast Asia (Cole 1986, Werner et al. 1991). They are the major biome of tropical and subtropical regions, occurring wherever rainfall is highly seasonal. Vegetation is sparsely wooded with a continuous $\mathrm{C}_{4}$ grassy understory (Huntley and Walker 1982, Sarmiento 1984, Tothill and Mott 1985a, Frost et al. 1986, Walker 1987, Solbrig et al. 1996), although they also incorporate other elements such as scattered heavily forested patches, riverine communities, and floodplains

Manuscript received 22 September 2006; revised 26 February 2007; accepted 26 February 2007. Corresponding Editor: T. J. Stohlgren.

${ }^{6}$ E-mail: aaron.petty@cdu.edu.au
(Scholes and Archer 1997). The differences among savannas are often described in terms of tree:grass ratios. Grassy savannas predominate in east Africa (e.g., the Serengeti) and central and northern South America (e.g., the Gran Chaco and Venezuelan llanos), while in south eastern Africa (miombo), southeastern Brazil (cerrados), the coastal plains of southeastern United States and Central America (pine savannas), and northern Australia (eucalypt savanna) wooded savannas predominate.

The determinants of savanna tree:grass ratios have been much studied (Belsky 1990), most recently by Scholes and Archer (1997), Higgins et al. (2000), Jeltsch et al. (2000), House et al. (2003), van Langevelde et al. (2003), Sankaran et al. (2004, 2005), and Gardner (2006). These studies are consistent in demonstrating that what seems like a node of stability in time is mainly a product of disturbance (e.g., fire, grazing, drought). It 
is the disturbance-dependent nature of savannas that makes them particularly susceptible to anthropogenic change, whether from direct management or the introduction of novel species. Indeed, savannas on every continent have experienced some degree of change in tree: grass ratios over recent decades or centuries, due especially to changes in management affecting grazing and/or fire (Sinclair and Norton-Griffiths 1979, San José and Fariñas 1983, 1991, McNaughton 1985, 1993, Menaut et al. 1985, 1990, Archer 1990, Stott 1990, Werner 1991, Scholes and Walker 1993, Glitzenstein et al. 1995, Chidumayo et al. 1996, Moreira 2000, Silva et al. 2001, Platt et al. 2002, du Toit et al. 2003, Sharp and Whittaker 2003, van Langevelde et al. 2003, Bond and Keeley 2005, and references therein).

The majority of these studies on savanna processes have focused on the role of grazing or fire in shaping savanna structure, but only a few have considered both simultaneously (e.g., Norton-Griffiths 1979, San José and Ferinas 1983, 1991, McNaughton 1993). The most applicable contrast to our study is that of NortonGriffiths (1979) who richly detailed the cascading effects of an 1890-1895 rinderpest epidemic that eliminated 95\% of the ruminant grazers of the Serengeti in East Africa. The number of ruminants remained well below historical levels for some 50 years until disease control measures gradually restored the population. The sudden removal of grazers from the savanna had a profound impact on plant, animal and human populations as well as fire regimes, and the effects were still evident some four decades after rinderpest was brought under control.

We report here on circumstances that invert the Serengeti experience. In the mid 1800s, English settlers introduced Asian water buffalo (Bubalus bubalis Lydekker; see Plate 1), a novel large herbivore, into the tropical savannas of central far north Australia, a continent whose biota have evolved, at least since the Pleistocene, in the absence of large grazers (Mulvaney and Kamminga 1999). As early as 1885 , Captain L. Carrington warned that, left unchecked, buffalo would become a "serious evil" (Carrington 1885). Indeed, buffalo expanded rapidly across several major river systems of the north within a century. Numbers grew rapidly to carrying capacity from 1960 to 1980 , and their ecological impact was recorded (Stocker 1972, Letts et al. 1979, Braithwaite et al. 1984, Taylor and Friend 1984, Ridpath 1991, Corbett 1995, Corbett and Hertog 1996, Skeat et al. 1996). In the 1980s, some 150 years after its introduction, a government-sponsored eradication campaign rapidly removed the buffalo from most of its range.

Only now has there been enough research at sufficient spatial and temporal scales for us to appreciate the extent of the cascading effects and long-term nature of the ecological changes caused by the rapid increase and subsequent decrease of buffalo. In this paper, we aim to (1) establish the historical pattern of buffalo abundance in a region of significant biological and cultural importance, using published, archival and oral sources and (2) investigate the secondary impacts of buffalo on structure and dynamics of three major vegetation types in the savannas of the region: floodplains, monsoon forests, and woodlands.

Like the rinderpest epidemic of the Serengeti, this situation provides "a rare opportunity to understand an ecosystem" (Sinclair and Norton-Griffiths 1979). The savannas of north central Australia are broadly similar in climate and structure to the mesic savannas of Africa and South America, with over $1000 \mathrm{~mm}$ of rainfall and an extended dry season (Sarmiento 1984, Menaut et al. 1985) but are generally oligotrophic and support a relatively low biomass of vertebrates (Mott et al. 1985, Braithwaite 1990). Unlike the savannas of Africa, but like the savannas of South America, Australia does not have native flora adapted to large ungulates. This had profound consequences for perennial and annual grass responses to grazing pressure in Australia.

This work also yields insights into the nature of niche competition and demographic processes in shaping savanna ecosystems in general, and informs current debate regarding the interaction between fire and grazing on shaping Australian savanna composition and structure (Fensham and Holman 1999, Sharp and Whittaker 2003, Archibald et al. 2005, Mills and Fey 2005). It also provides an example of the cascades of effects that can flow through ecosystems when a major restructuring agent (large grazer) is added or subtracted from the system. Finally, it is a case study in the application of historical ecology to contemporary management questions, demonstrating that both environmental and historical factors must be considered when attempting to make sense of observed landscape scale changes.

\section{Methods And Frameworks}

\section{Location and biome}

Buffalo ranged across most of north-central Australia, colloquially referred to as the "Top End" (Fig. 1). The densest populations of buffalo and the longest management history were in the Alligator Rivers Region (ARR; Finlayson et al. 1997), a region of approximately $28000 \mathrm{~km}^{2}$ that encompasses three large tidal river systems: the East Alligator, South Alligator, and West Alligator Rivers. Climate, hydrology, geology, and biotic elements of the ARR are described in detail in Finlayson and von Oertzen (1996). The present Kakadu National Park (KNP), a World Heritage area, is bounded by the ARR. Because KNP was established over three stages, from 1974 to 1987 (Press et al. 1995), we often refer to the ARR in historical terms as required, but with the understanding that most of this same area ultimately became KNP.

The ARR was the location of both the earliest buffalo hunting leases and the most thorough attempts at population control and eradication. The park is considered to be particularly pristine ecologically, with no known extirpations and relatively few exotic fauna 

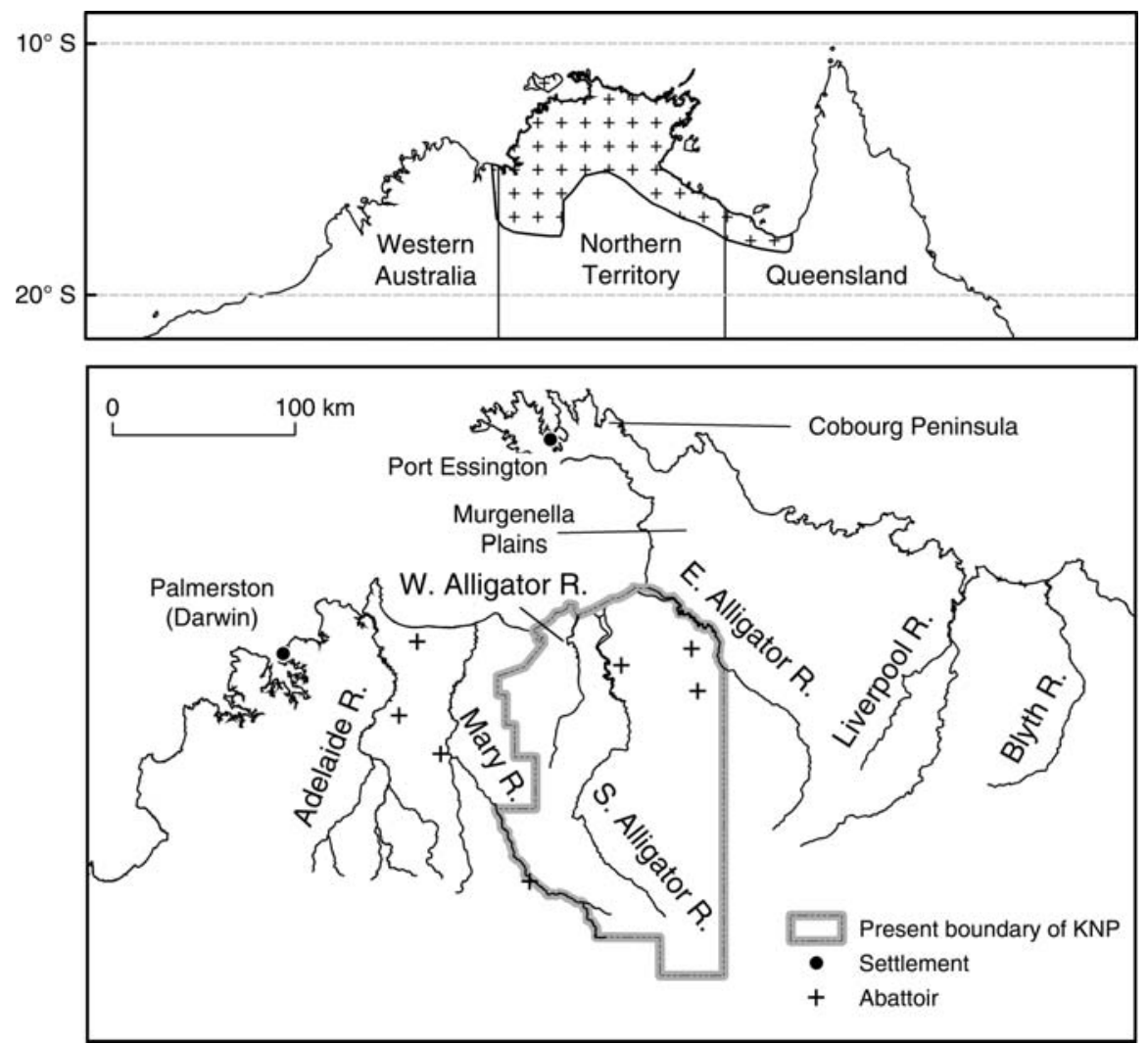

FIG. 1. The top map shows northern Australia ("Top End") and the maximal extent of the buffalo invasion in Australia (adapted from Letts et al. [1979]). The bottom map shows the core buffalo region, including the Alligator Rivers Region and Kakadu National Park, the historical locations of abattoirs, and the location of the earliest settlements in the Top End, Port Essington, and Palmerston (present-day Darwin).

(Braithwaite and Werner 1987, Press et al. 1995, Woinarski et al. 2001), although there are six non-native mammal species (Ridpath 1991). Exotic plants are mainly confined to disturbed ground and riparian communities (Cowie and Werner 1993). The ecological focus of our paper is KNP, with references to the larger region as required by historical narrative.

For the paper, we use the term "savanna" in the sense of Scholes and Archer's (1997) term "savanna landscape," a biome with many elements including open, sparsely wooded vegetation, closed-canopy monsoon forest, and open, herbaceous floodplains. To avoid confusion we use the simple word "woodland" for the dominant sparsely wooded vegetation community commonly called "savanna" or "savanna woodland."

\section{Sectors of Kakadu National Park}

In our work, we discovered that reconciling historical records and ecological studies of impacts made sense only when we divided KNP into three sectors: northern, central, and southern. These roughly correspond to Stage 2 of KNP (declared a national park in 1984), Stage 1 (1979), and Stage 3 (1987), respectively (Levitus 1995; Fig. 2a). These sectors reflect the different social histories of KNP as well as the different dates of buffalo encroachment as they moved southward. They differ in relative cover of the main vegetation types (more floodplains in the north and woodland in the south; Fig. 2b), and soils (low lying, poorly drained, clay soils are common in the northern sector; uplifted Proterozoic sandstone with shallow, sandy soils dominate the southern sector [East 1996]). A rainfall gradient spans the sectors, decreasing from an average of $1380 \mathrm{~mm} / \mathrm{yr}$ in the north to $1150 \mathrm{~mm} / \mathrm{yr}$ in the south (Fig. 2c).

The northern sector is dominated by the floodplains and tidal channels of all three of the Alligator Rivers. By far the largest in extent and volume is the South Alligator River. In the wet season, the South Alligator floodplains span some $5-10 \mathrm{~km}$ on either side of the central channel and, in the dry season, a twice-daily tidal bore advances some $90 \mathrm{~km}$ inland, into the central sector. The major floodplains in the northern sector are interspersed with lateritic upland ridges of savanna woodland dominated by Eucalyptus miniata A. Cunn. ex Schauer and Eucalyptus tetrodonta F. Muell.

The central sector extends across a region of freshwater floodplains, seasonally inundated savanna, and drier upland savanna lying $60-80 \mathrm{~km}$ inland from the coast. It includes a special wetland complex of some $200 \mathrm{~km}^{2}$ where the South Alligator River discharges 

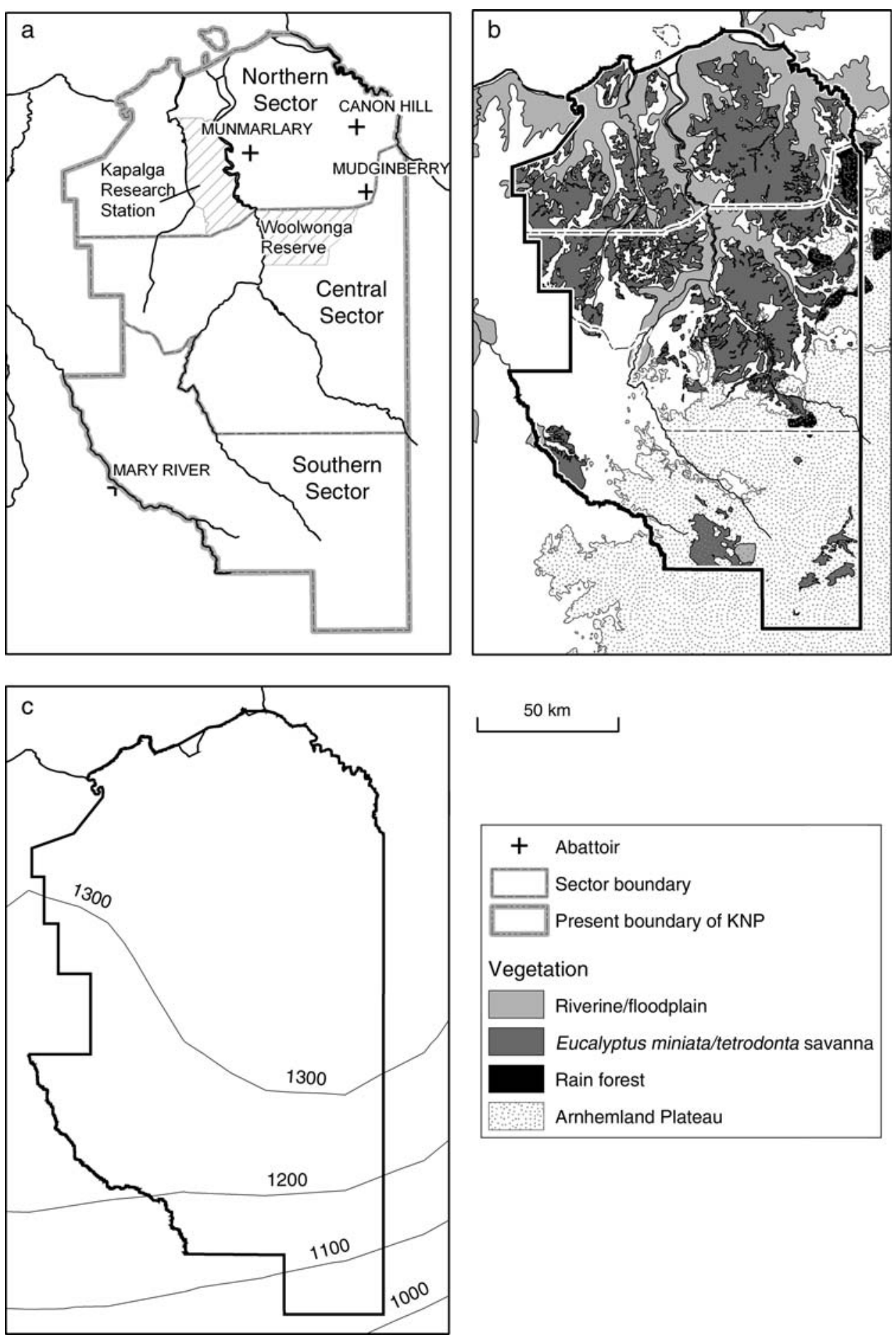

FIg. 2. Maps of Kakadu National Park (KNP): (a) details of the biogeographic and historical sectors of Kakadu National Park, as well as the location of abattoirs within the Alligator Rivers Region, and the location of the former Woolwonga Reserve (1936-1979) and Kapalga Research Station (1974-1996); (b) the major vegetation communities of Kakadu National Park (unshaded areas are generally other wooded savanna); (c) a map of rainfall isohyets, in $\mathrm{mm} / \mathrm{yr}$. Vegetation data are from Schodde et al. (1987) and Wilson et al. (1991). Rainfall data are derived from gridded monthly climate data at $0.25^{\circ}$ of latitude-longitude from the National Climate Centre of the Bureau of Meteorology Research Centre, Melbourne, Australia. 


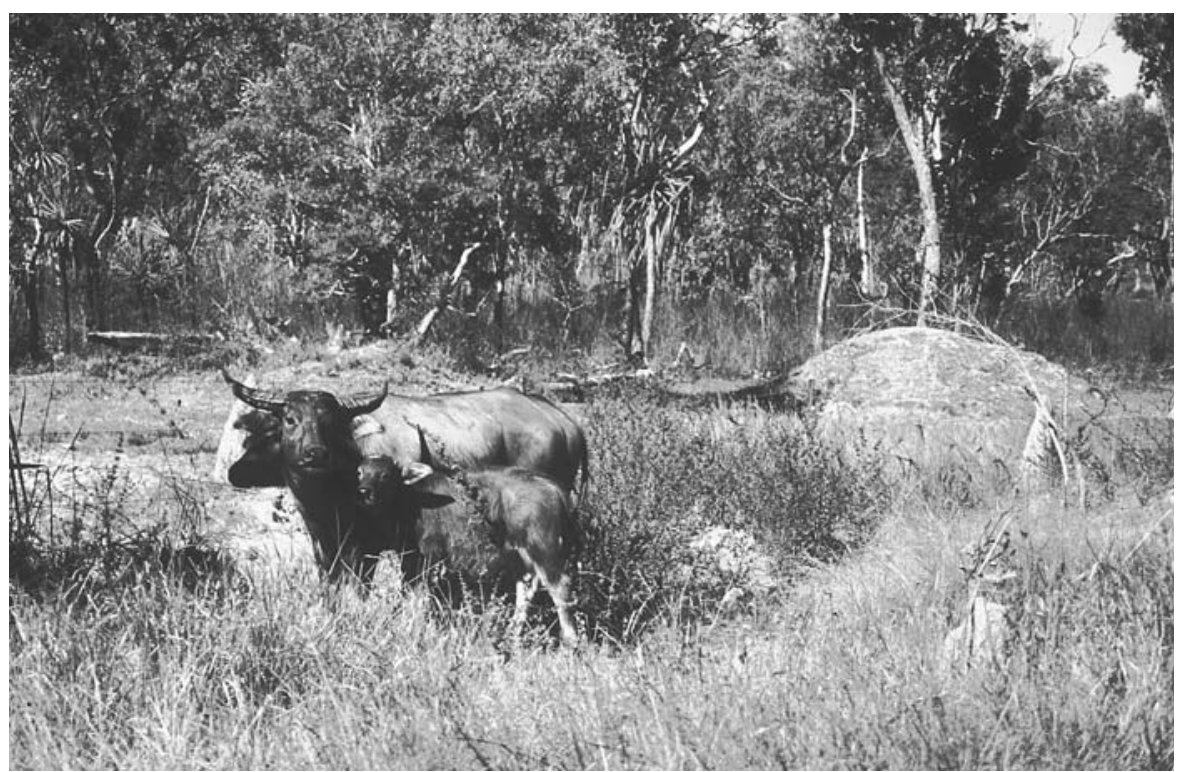

Plate 1. A buffalo cow and calf in the buffalo farm (central sector, Kakadu National Park, Australia). The exotic weed Hyptis suaveolens forms a clump to the right of the buffalo and also infests the woodland edge in the background. Photo credit: A. Petty.

freshwater into a vast network of floodplains and perennial and seasonal billabongs that in turn eventually drain into a tidal channel. The central sector also includes Jim Jim Creek, a major tributary of the South Alligator River characterized by braided streams, perennial billabongs, and an admixture of paperbark (Melaleuca spp.) swamps, seasonally inundated open woodland savanna, and upland Eucalyptus miniata/E. tetrodonta woodland savanna.

The southern sector incorporates a large area of upland plateau, part of the Arnhem Land Plateau, to the east and south, and large outwash plains and lowland savanna woodlands to the west. Both the plateau and the lowland savanna woodlands are interspersed with numerous perennial and seasonal creeks. The southern sector was formerly two large pastoral properties, and was the last sector to be incorporated into KNP in 1987 (Press et al. 1995), well after eradication efforts were underway in the northern and central sectors.

\section{Ecological cascades}

The ecological impacts of buffalo differed across sectors depending on the local buffalo population, vegetation community and edaphic factors. Our understanding of these complex ecological processes and impacts is greatly enhanced by recognition of the ecological chain of impacts initiated by the rapid increase and decline of buffalo. We have constructed two ecological cascades that operated during two different times: (1) the period of increase in buffalo densities, from 1960 to 1980; and (2) the period of rapid decline in buffalo densities, 1980-1994.

During each of these cascades, the rapid increase or decline of buffalo densities directly altered ground cover abundance and composition. Buffalo often stripped ground vegetation bare as they approached carrying capacity in the first cascade. Conversely, ground vegetation, particularly annual grasses, were released by buffalo decline. In general, the direct effect of buffalo on ground level vegetation and soils indirectly altered competitive relationships among trees, grass and forbs, as well as produced large changes in fuel loads and fire regimes which, in turn, further altered species composition and overall structure of the savanna. The second cascade, with the reversal in grazing pressure, also included significant hysteresis effects within the vegetation (Werner 2005, Werner et al. 2006) and released resources to other feral animals which then increased in numbers (Corbett 1995).

\section{The History of Buffalo in Northern Australia}

Introduction, dispersal, and increasing population density

Buffalo were first introduced to mainland Australia from 1825 to 1829 in several small shipments totaling no more than 100 individuals to Port Essington and Raffles Bay on the Cobourg Peninsula (McKnight 1976, Ridpath 1991). As the original settlements were abandoned, these buffalo were left behind and their descendants expanded across the peninsula. In 1844, the explorer Ludwig Leichhardt reported buffalo grazing on the Murgenella Plains, immediately south of the Cobourg Peninsula and approximately $80 \mathrm{~km}$ from the Alligator Rivers Region (Leichhardt 1884). Once they passed through the hilly and relatively inhospitable neck of Cobourg Peninsula, buffalo rapidly expanded across the coastal riverine plains. In an 1862 expedition along the Mary River coastal plain, John McDouall Stuart reported no buffalo sightings, but by 


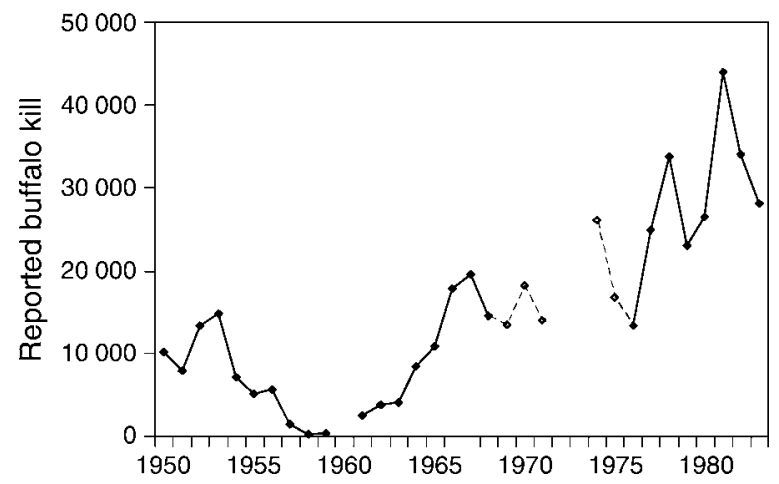

FIG. 3. Reported number of buffalo taken for both domestic consumption and export, by year. Data for relevant years are derived from The Northern Territory Reports 19491953, 1953-1955, 1955-1956, 1956-1957, 1958-1959, 19671968, 1970-1971, 1971-1972; The Northern Territory Agricultural Branch Annual Reports 1959-1960, 1962-1963; The Northern Territory Animal Industry Branch Annual Reports 1960-1961, 1961-1962, 1964-1965; The Northern Territory Animal Industry and Agriculture Branch Annual Report 19661967; The Northern Territory Primary Industry Branch Annual Report 1966-1968; The Northern Territory Department of Primary Production Annual Reports 1979-1980, 1980-1981, 1981-1982; and minutes from the Buffalo Producers' Council 18 November 1987 (NT Archives NTRS 669/P1). Values for 1969-1971 are estimates from the value of buffalo exported; head counts are not supplied. Values for 1974 and 1978 are derived from Letts et al. (1979). Values for 1975-1977 are from Ridpath (1991) using data derived from Letts et al. (1979).

1885 they had expanded at least as far as the Adelaide River to the west and the Liverpool River to the east (Lindsay 1884 as reported in Letts et al. 1979, Ridpath 1991). In the Alligator Rivers Region, buffalo were abundant around the East Alligator River by 1885, and were present but scarce around the South Alligator River (Fig. 1). Paddy Cahill, a famous early settler in the ARR, hunted buffalo around Kapalga, near the mouth of the South Alligator River by 1899, and likely 1895 . $\mathrm{He}$ indicated that buffalo were common, if not abundant, near the South Alligator at this time (Mulvaney 2004).

The expanding feral buffalo population became an economic resource for the Top End with the rise in demand for buffalo hides for use as belting in industrial machinery. Hide hunting began in the 1880 s, but did not gain momentum until the turn of the century, both from increased demand overseas and, locally, the introduction of a more efficient means of horseback shooting (McKnight 1976). In 1900, 1645 hides were exported from the Northern Territory (Northern Territory of Australia Office of the Government Resident 1901), and exports climbed rapidly thereafter. Hide exports for the Northern Territory generally remained above 5000 per annum from the early 1900s and remained high for over half a century. So important were buffalo to the economy that in 1920 the Northern Territory's acting administrator recommended protecting buffalo as they were "fast becoming extinct on the mainland" (Parlia- ment of the Commonwealth of Australia 1921). However buffalo hide exports continued to climb unabated after 1920 with no discernable impact on populations. McKnight (1976) suggested that, contrary to administrative concerns, market demand, and not population fluctuations, drove buffalo exports.

The hide industry collapsed in 1956 soon after synthetic materials replaced buffalo leather for industrial belting. In the space of a year, hide exports in the Northern Territory dropped from 5663 to 100 hides (McKnight 1976). After a brief hiatus, exports again increased, and harvests in the 1960s and 1970s well exceeded those of the hide era (Fig. 3). This was due both to local demand for buffalo for meat and pet food, and an initiative of the Northern Territory Agricultural and Animal Industry Branch to redevelop buffalo as a viable economic resource for the Top End (Northern Territory Administration Animal Industry Branch 1961). Reported buffalo take in the Northern Territory rose from under 300 in 1959 to 3077 in 1962 to over 13000 by 1967 (Department of Territories 1959, Northern Territory Administration Animal Industry Branch 1962, 1967; Fig. 3) although these estimates are likely conservative, given the largely unregulated trade in pet meat in the 1960s (Ridpath 1991). In 1961, the Northern Territory Animal Industry Branch reported that "the value of production from buffaloes was greater than since 1955, and the buffaloes killed were more fully utilized than ever before" (Northern Territory Administration Animal Industry Branch 1961). In 1972 buffalo removal for commercial purposes had peaked at approximately 30000 head.

Despite increasing rates of buffalo harvest, the aerial photographic record, anecdotal accounts, and government reports indicate that buffalo densities were increasing rapidly from 1960 to 1980 (Fig. 3), with peak densities reached throughout the region. Under ideal conditions of high dry season rainfall, abundant surface water, and no hunting pressure, buffalo populations have the capacity to increase exponentially to the carrying capacity of the environment within approximately two decades (Freeland and Boulton 1990, Skeat 1990, Skeat et al. 1996). In good rainfall years, harvest rates must approach $10 \%$ to have a chance of reducing buffalo populations within a reasonable time (Freeland and Boulton 1990, Boulton and Freeland 1991). Although no accurate regional counts of buffalo were made until 1981 (Ridpath 1991), several lines of evidence indicate that buffalo had reached carrying capacity before then. In general, population numbers increased, with some declines principally due to natural mortality from reduced landscape carrying capacity during years of low or late wet season rainfall. Tulloch (1968) estimated that over 20000 buffalo died of starvation in "bog holes" due to late rains in 1965. D. Lindner (personal communication) recalled a similar event killing large numbers of buffalo in 1972. Nevertheless, by 1981 the Northern Territory buffalo population had clearly 
rebounded, and an aerial survey by Graham et al. (1982) estimated the Northern Territory buffalo population at 280000 , slightly higher than Letts' (1964) estimate of 150000-200000 buffalo within the lowland sub-coastal plains immediately after the collapse of the hide industry.

Despite their exploitation for economic gain, buffalo had expanded in less than 150 years from an isolated population of fewer than 100 individuals to become the most abundant large grazing and browsing mammal across the coastal plains of the Top End (Bayliss and Yeomans 1989), and a significant environmental concern (Letts et al. 1979). It took the concerted effort of a largescale government campaign to reduce buffalo numbers to the point that they were no longer a visible environmental force in the Alligator Rivers Region.

\section{Eradication campaign and rapid decline}

Buffalo eradication began as a means of enabling the certification of Top End beef for export by controlling tuberculosis and brucellosis infection rates among domestic cattle (Letts et al. 1979). A Board of Inquiry was established in 1970 and determined that feral animals, particularly buffalo, were a major source of concern for the cross infection of domestic bovine herds. The Brucellosis and Tuberculosis Eradication Campaign (BTEC) began with the mustering of live animals and then ground shooting of the densest feral buffalo herds on the northernmost floodplains in 1980. By 1987, buffalo density in KNP had been reduced to fewer than $1 \mathrm{buffalo} / \mathrm{km}^{2}$ (Skeat et al. 1996), and eradication efforts turned toward the last remaining populations of buffalo, located in the isolated rain forest pockets and ravines of the rugged Arnhem Land plateau. In 1989, KNP turned to helicopter eradication to remove any remnant populations. By the completion of the campaign in 1992, the buffalo population had been reduced to fewer than 0.01 buffalo $/ \mathrm{km}^{2}$ (Robinson and Whitehead 2003), although parts of neighboring Arnhem Land retained substantial populations of buffalo (P. Bayliss, unpublished data).

BTEC was a remarkable success in eradicating feral buffalo from KNP and the Top End at large, but remains highly controversial to this day, particularly among both tour operators and Aboriginal communities (Lucas and Russell-Smith 1993, Robinson and Whitehead 2003, Robinson 2005), who have seen the campaign as a threat to their livelihoods. With the exception of a few domestic herds, most remnant buffalo populations have been left largely unchecked since BTEC, and they are again expanding in KNP, particularly within the southern sector as buffalo immigrate from Arnhem Land.

\section{The Historical Ecology of Buffalo in Kakadu National Park \\ Introduction and dispersal within KNP}

As elsewhere in the Top End, the closest and best habitats for buffalo in the Alligator Rivers Region were along the northern coastal plains, and this was also the first point of contact between hide hunters and buffalo. Explorers' records indicate buffalo herds were in the northern sector of KNP by the late nineteenth century. By the early 20th century, this sector supported a thriving buffalo hide industry. Traces of buffalo tracks and wallows are abundant in 1950 aerial photos of northern reaches of the Mary River, a river system comparable to the South Alligator River, but some 100 $\mathrm{km}$ to the west (Stocker 1972, Petty et al. 2005). Movement of breeding herds southward probably did not occur until buffalo had expanded to relatively high population densities in the north. Not only were southern areas less suitable, but individual buffaloes, particularly cows and calves, typically have restricted ranges and outward dispersal of breeding herds can be relatively slow (Tulloch 1978). Indeed, our visual inspection of the aerial photographs of the floodplains of the central sector of KNP shows little evidence of buffalo tracks and wallows in 1950, although they are abundant there, and in the southern sector, by 1964 .

The anomalies in population dynamics of buffalo herds across the three sectors are correlated to both habitat quality and human activity. Although the area of habitat most suited to buffalo is most extensive in the north and decreasing southerly through KNP, a history of abattoirs in the northern sector and a conservation reserve in the central sector acted to reduce local population numbers. By contrast, dispersal into the southern sector occurred quite late, but buffalo numbers were left relatively unchecked.

\section{Northern sector}

The vegetation and topography of the north coastal sector are ideal for buffalo as the woodlands on the lateritic ridges of floodplain margins provide camping and resting habitat for groups of cows and juveniles, as well as access to fodder during the end of the dry season and during peak floods, when food resources are scarce on the floodplains (Tulloch 1969, 1970, 1978).

Before 1960, buffalo hides were intensively hunted on both sides of the South Alligator River, although the western side was arguably better known as the site of Kapalga, the hunting lease of the famed buffalo hunter Tom Cole (Cole 1988). After the collapse of the hide industry, the western sector saw little buffalo management apart from informal hunting for pet meat and domestic consumption. By contrast, on the eastern section, three abattoirs were developed in the 1960s, at Mudginberri, Cannon Hill, and Munmarlary (Fig. 2a). At their peak, these abattoirs processed over $50 \%$ of the Northern Territory's buffalo meat (Northern Territory Administration Animal Industry and Agriculture Branch 1967). The last of the abattoirs, at Mudginberri, was closed in 1987.

By the early 1980s the northwest had the highest population densities of buffalo in the whole Alligator Rivers region, as high as 34 buffalo $/ \mathrm{km}^{2}$ on the South 


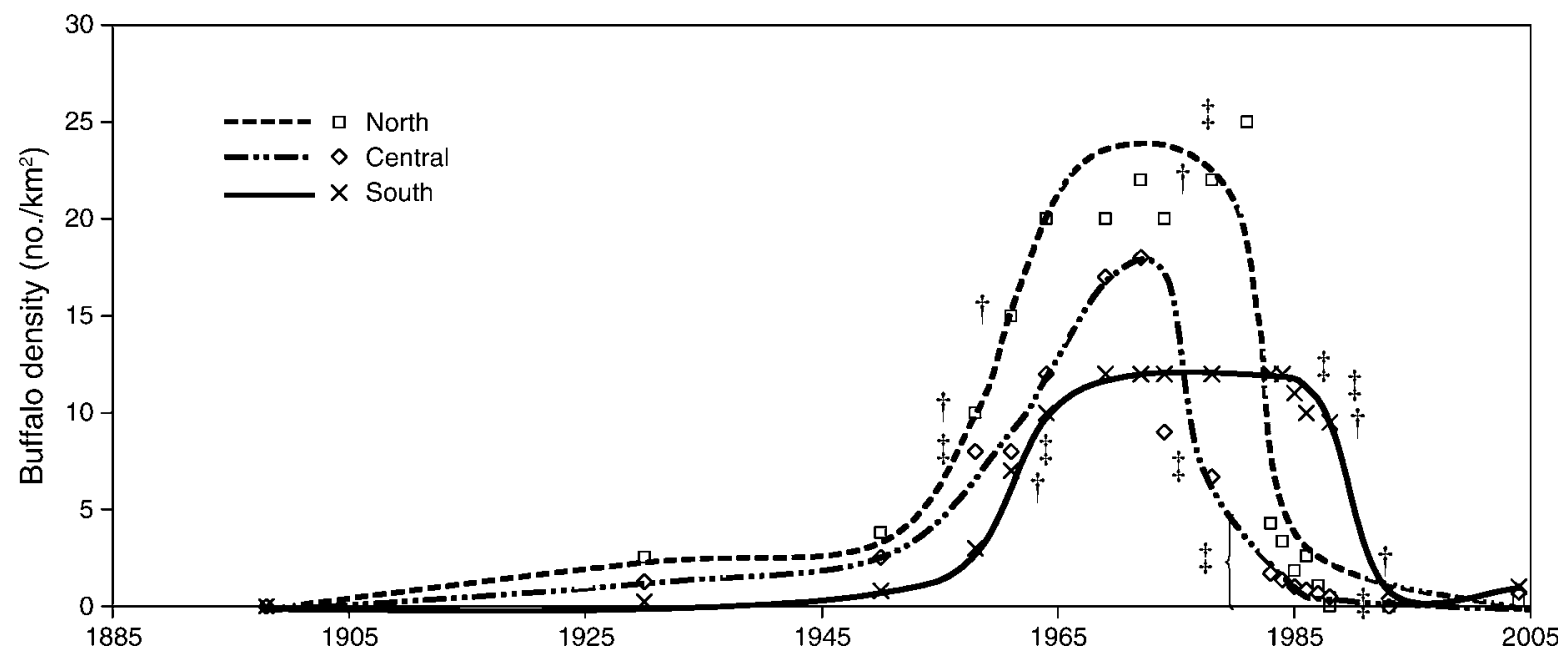

FIG. 4. Estimated buffalo population numbers in the Alligator Rivers Region (ARR). A single dagger ( $\dagger$ ) indicates data inferred from population estimates of the ARR in published sources or from oral history. Data points marked with a double dagger (\$) are population estimates obtained directly from published sources. Other data are inferred estimates from remarks and reports on buffalo in historical written records and oral history. Data are derived from Carrington (1885), Letts (1964), Stocker (1972), Christian and Aldrick (1977), Letts et al. (1979), Cole (1988), Skeat (1990), Ridpath (1991), Robinson and Whitehead (2003), Mulvaney (2004), T. Hill (personal communication), and A. Fisher (personal communication).

Alligator River floodplains at Kapalga (Ridpath et al. 1983, Ridpath 1991; Fig. 4). In aerial counts taken in 1985, Bayliss and Yeomans (1989) reported population densities that were $5-10$ buffalo $/ \mathrm{km}^{2}$ for the west, and $0.1-5$ buffalo $/ \mathrm{km}^{2}$ in the east, although both sides had localized regions with much higher population densities.

Within the Alligator Rivers region, the tuberculosis infection rate among buffalo was highest in the northern sector, and this sector received early and sustained attention from the BTEC campaign (Robinson and Whitehead 2003). This caused a precipitous drop in buffalo numbers (Fig. 4). In 1983, the population averaged 4.3 buffalo $/ \mathrm{km}^{2}$ across both east and west portions of the northern sector, but by 1988 the population density had dropped to fewer than $1 \mathrm{~km}^{-2}$ (Skeat 1990, Robinson and Whitehead 2003).

\section{Central sector}

Overall, buffalo never attained the levels seen in the northern sector (Fig. 4). However in the freshwater floodplains of the central sector buffalo were as numerous, and their impact as extensive, as in the larger northern sector.

The growing impact of buffalo on the floodplains of the central sector was the subject of increasing concern for the land managers and Aboriginal residents of the Woolwonga Aboriginal Reserve (Fig. 2a), established in 1936 as the first protected area in the ARR and in 1964 designated a conservation reserve (Lucas and RussellSmith 1993). Yorky Bill Alderson, a famed buffalo hunter who was raised in the ARR, also attested to the impact of buffalo in the Jim Jim Creek area: "The Wet is all right for them [buffalo], but in the Long Dry every year, from May to October and sometimes November, they must reckon they're in the wrong country, too. They're a damn pest, a menace. When I was a boy the Jim Jim was much better country than it is now; cattle won't graze with buffs, and they've destroyed hundreds of miles of it." (from Lockwood 1979:49-50).

In 1974, reserve managers instituted a program of buffalo removal both in the reserve and in neighboring areas (Letts et al. 1979). Dave Lindner, who was employed on the reserve at the time of the program, estimated that $90 \%$ of the buffalo were eradicated from floodplains, and that this action created a marked return of grasses that had previously been grazed out from these areas (Petty et al. 2005; D. Lindner, personal communication). The decline in numbers of buffalo during this culling action is reflected in the aerial photographic record of the area. By 1984, tidal channels damaged by buffalo showed signs of self-repairing, a date too early to be a result of the later BTEC reductions (Fig. 5a). In contrast, on the western side of the South Alligator River, vegetation seemed to have suffered heavier damage from buffalo than the east side (Fig. 5b). As in the northern sector, the differences in environmental impact on the two sides of the South Alligator River are consistent with the history of the sector, as there were no extensive buffalo hunting activities, either for culling or trade, on the western side.

Also like the northern sector, virtually all wild stocks of buffalo were eradicated by BTEC. However, in 1993 a local Aboriginal corporation set up a domesticated herd of some 350 buffalo as a source of buffalo meat for local Aboriginal communities. Today, this buffalo farm manages a herd that varies between 600 and 1000 head within fenced 12000 ha. It provides valuable information on the impact of buffalo on vegetation as well as 
best management practices in controlled herds in these types of landscapes (Riley 2005).

\section{Southern sector}

The numerous perennial and seasonal creeks of both the plateau and lowlands of this sector provide suitable, if not ideal, habitat for buffalo. Data on the sector are sparse, but anecdotal accounts indicate that buffalo did attain high population densities locally, particularly in the lowland woodland savannas to the west of the escarpment (T. Hill and A. Fisher, personal communication) The ruggedness and isolation of the plateau provided buffalo a refuge from hunters and they likely achieved carrying capacity rather quickly once they had dispersed into the area (Fig. 4).

Historically, cattle were the focus of economic activity in the sector, and the closest abattoir, Mary River, located just outside the present day boundary of KNP, ran a small operation that never approached the processing rates achieved at the abattoirs to the north (Northern Territory Administration Animal Industry and Agriculture Branch 1967). Alan Fisher worked as a musterer for both pastoral properties prior to their incorporation into KNP, and was retained to de-stock the properties when they were acquired by the park. He witnessed buffalo becoming increasingly common throughout the 1980s: "Back in the old days [late 1970], we'd go out in the dry season to bring in over three-year bulls for Mary River. It took a while for us to find some. A few years later it wasn't uncommon to find a few small groups. Then, later, we'd see hundreds of them" (A. Fisher, personal communication).

When the BTEC campaign turned its attention to the southern end of the park in 1987, unexpectedly high numbers of buffalo were found. Their numbers made buffalo too valuable of an economic resource and the strategy turned from helicopter shooting on site to helicopter mustering for shipping to an abattoir (T. Hill, personal communication). In the space of three years, Alan Fisher (personal communication) estimates that over 45000 buffalo were removed from this sector. Other reports indicate the population density dropped from over 10 buffalo $/ \mathrm{km}^{2}$ to fewer than 1 buffalo $/ \mathrm{km}^{2}$ from 1986 to 1991 (Skeat 1990, Robinson and Whitehead 2003).

The plateau region of western Arnhem Land, which abuts the eastern side of the southern sector, never received much attention during the BTEC campaign as brucellosis and tuberculosis infection rates were very low, and there was little motivation to shoot buffalo on Aboriginal freehold land. A. Fisher (personal communication), found it difficult to meet the BTEC destocking quota because of continual migration of buffalo into KNP from Arnhem Land. Today this region remains a major source of buffalo migration into KNP, particularly in the southeastern corner, which has the highest densities of buffalo in KNP today (R. Muller and P. Bayliss, personal communication).

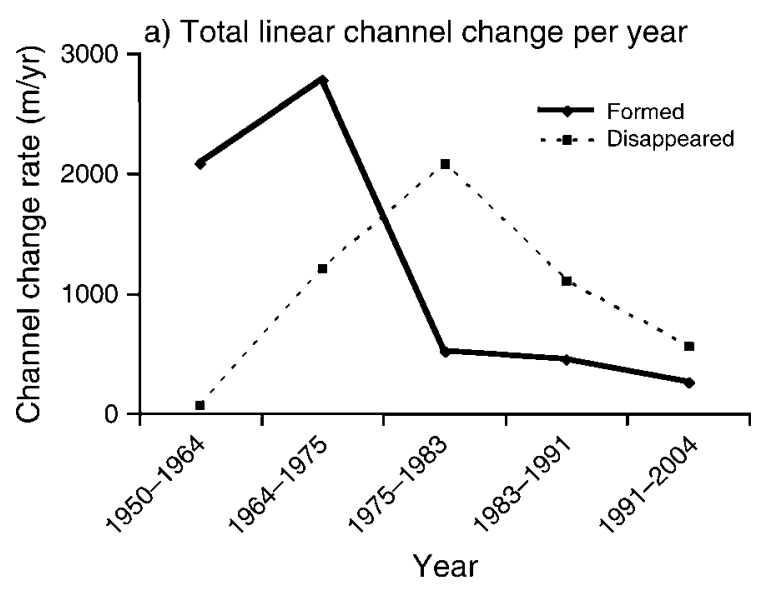

b) Cover of woody vegetation

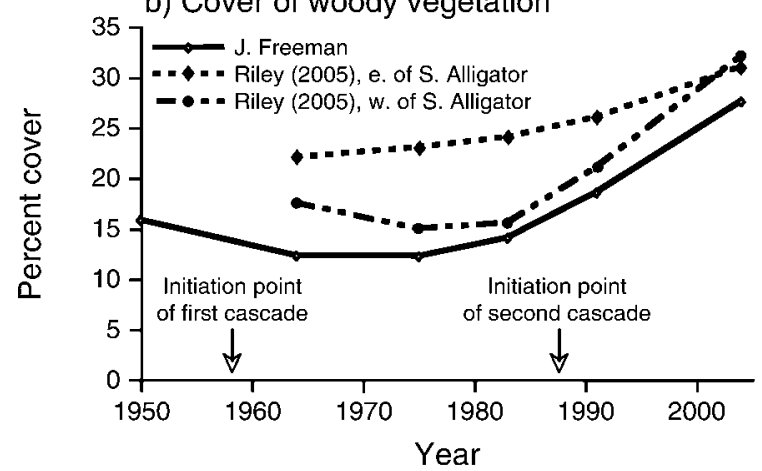

c) Channel formation rate and buffalo impact

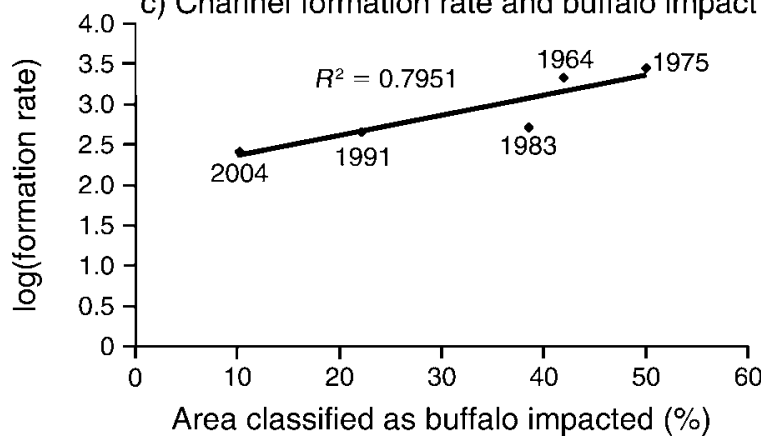

FIG. 5. Buffalo impact on floodplain vegetation and channels. All data were derived from 1950, 1964, 1975, and 1983-1984 orthorectified aerial photomosaics of the South Alligator River floodplains in the central sector of Kakadu National Park (KNP). (a) Linear channel change rate was calculated as the difference in total channel length between time periods for all channels that were absent in the earlier photo (formed) and for all channels that were absent in the more recent photo (disappeared). Data are from Petty et al. (2005). (b) Woody vegetation cover was calculated from two different studies of geostationary points spaced across the South Alligator Floodplain in the central sector. The arrows illustrate the initiation points of the two ecological cascades. Data are from Riley (2005) and J. Freeman (unpublished data). (c) Logtransformed rate of channel formation (measured as $\mathrm{m} / \mathrm{yr}$ ) compared with percentage of geostationary points where aerial photos showed visual signs of buffalo impact (tracks and wallows). Data are from Petty et al. (2005) and J. Freeman (unpublished data). 


\section{ECOLOGICAL IMPACTS OF BufFalo}

Most of the research on the ecological impact of buffalo has focused on wetland environments, with little attention to the impact on habitats such as woodland savanna and rain forests. Further, the substantial anecdotal and photographic evidence of the dramatic effects of buffalo on the landscape were almost entirely confined to the floodplains, seasonally inundated fringing lands, and other riparian areas where buffalo impact was most visible and human-buffalo coexistence was closest. Here, we consider the impact of buffalo expansion and decline in three major habitat types: floodplains, monsoon rain forests, and savanna woodlands.

Given that the three sectors of KNP are made up of different relative areas of these three major habitat types, one would expect that the overall impact per sector would be quite different. Further, given the general north to south gradient in buffalo numbers (Fig. 4 ), one might assume a greater ecological impact in the northern sectors of KNP. However, the differences in both the resilience of the various habitats and the carrying capacity across the north-south gradient must be taken into consideration, with any impact of numbers scaled relative to the capacity of the land to produce green biomass.

We posit that lower rainfall and lower plant productivity in the southern sector of the park, as well as long-sustained buffalo populations at or near carrying capacity, historically produced as great an ecological impact in the southern sector as in the northern sector. The evidence of impact in the north is well recorded, whereas the record of environmental impacts in the south is limited to aerial photography, which shows no change in woody cover. However, aerial photography says nothing of the condition of understory vegetation, which surely changed with buffalo grazing. The situation is also confounded by the impact of other feral animals, including cattle and horses, which, in the southern sector, reached numbers as high as buffalo in some places (A. Fisher, personal communication). Nevertheless, A. Fisher (personal communication) recalls that most visible environmental damage on the plateau was restricted to riparian corridors and other areas of dense canopy cover that were the preferred habitat of buffalo. Skeat et al. (1996) and East (1990) reported extremely high sediment loads in the South Alligator catchment along the Arnhem Land plateau which they attributed to buffalo activity. Similarly, buffalo were implicated in increased fire damage within the monsoon rain forests that line the gullies of the plateau of the southern sector (Russell-Smith 1984).

\section{Floodplains}

Several broad surveys of floodplains were produced during the period of peak buffalo impact, especially concentrating on lowland seasonally flooded black clay plains, and perennial billabongs, where buffalo numbers were generally very high and soils typically highly erodible (Fogarty 1982, Graetz 1989, East 1990). The South Alligator River floodplains and the Cooinda/Jim Jim flood basin, formed over silty and sandy alluvium, are particularly susceptible to erosion and degradation, whereas the East Alligator and West Alligator River floodplains, located over sand and clay-sand soils, were much less severely degraded (Graetz 1989, East 1990). It is from heavily grazed wetlands such as these that we have the most information about the ecological impacts of buffalo (Stocker 1972, Letts et al. 1979, Fogarty 1982, O'Neill and Matthews 1983, Friend and Taylor 1984, Taylor and Friend 1984, Graetz 1989, Corbett and Hertog 1996), including more recent reviews of broad scale buffalo impact on floodplains produced after the BTEC era (Skeat et al. 1996, Finlayson et al. 1997). Lucas and Russell-Smith (1993) provide a comprehensive report of anecdotal accounts of buffalo impact on floodplains and riparian communities. Further documentation is available from the results of a landscapescale exclusion experiment from 1981-1989 at Kapalga (Ridpath and Waithman 1988, Werner 2005) as well as surveys of vegetation and channel changes in the central sector using aerial photographs (Petty et al. 2005, Riley 2005).

A 1919 description of the floodplains at Cannon Hill near the East Alligator River describes "wonderful grassy plains" covered with "beautiful green, water couch grass" (Warburton 1944), whereas in the dry season of 1979, the same flood basin was black clay heavily pug marked from buffalo activities and almost completely bare of vegetation (Skeat et al. 1996). Paddy Cahill describes crossing the tidal head of the South Alligator River on horseback in 1901 at a location that is today scoured by a deep tidal channel (Mulvaney 2004). Grasses such as Hymanachne acutigluma (Steud.) Gilliland and Phragmites vallatoria (Pluk ex L.) Veldkamp were apparently common across the area prior to the explosion in buffalo numbers between 1960 and 1980. Lewis (1922) describes stands of "reeds" (likely Phragmites) from which he constructed a raft while trying to cross the East Alligator in 1887. In 1946, Christian and Stewart (1953) described grasses as very abundant on the coastal plains, including Hymenachne acutigluma at Cannon Hill, but by 1972-1973, Story (1976) found that grasses were very scarce in the same estuarine alluvium, noting the great change over the previous 26 years. More recent recollections of Aboriginal residents in KNP recall widespread stands of Phragmites from which they made spears (O'Neill and Matthews 1983). By 1996, Hymenachne was completely absent from Cannon Hill, and Phragmites was virtually absent from both Cannon Hill and the South Alligator flood plain (Skeat et al. 1996).

First cascade: buffalo population eruption.-Most documented observations of the direct buffalo impact on the floodplain surface come from scientific reports during the 1960s through 1980s, and are well summa- 
a

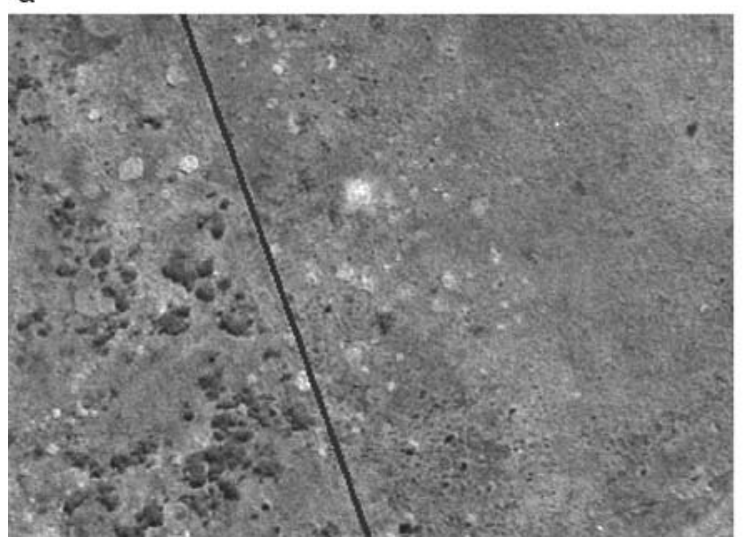

b

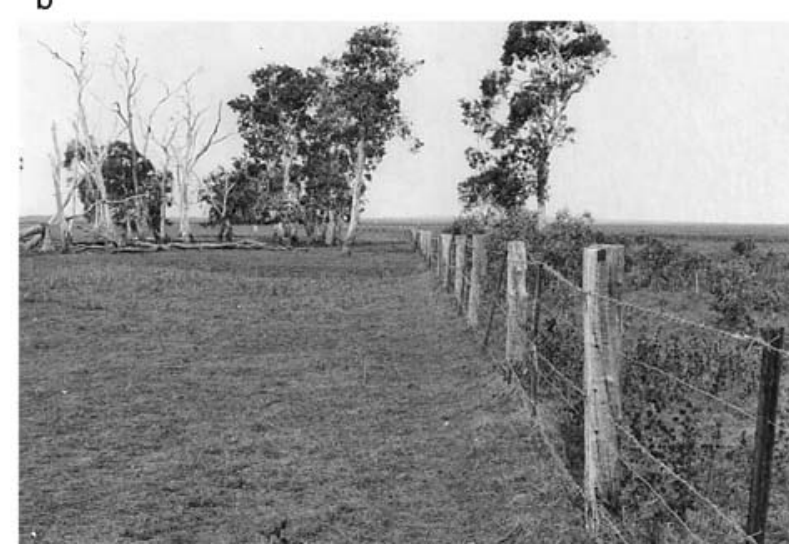

FIG. 6. These photographs highlight differences in floodplain woody vegetation cover in buffalo-impacted and non-impacted regions, separated by fence lines. (a) A 2004 aerial photograph with a highlighted fence line diagonal across the image. The fence separates the buffalo farm in central Kakadu National Park (KNP; right) from KNP proper, which at present has very low buffalo numbers (photo courtesy of KNP). (b) A ground photograph taken at Kapalga in 1984 contrasting a buffalo-excluded area (right) from an area with buffalo (photo by Don Tulloch).

rized by Skeat et al. (1996). These impacts, including wallowing, track and pad formation, and compression of soils, resulted in the siltation of streams, increased turbidity and eutrophication of water bodies, reduced vegetation and pedestal, rill and gully erosion (Skeat 1990). Buffalo also impacted hydrology directly by creating small channels and depressions which were further deepened by wet season runoff, and increasing sheet erosion from decreased water-retention capacity in compacted soils (Noble and Tongway 1986, Skeat et al. 1996).

However, the largest landscape-scale buffalo impact in the Alligator Rivers Region was mediated through grazing and its impact on standing plant biomass, both green and litter. At the high population densities seen in the South Alligator River floodplains, buffalo removed most of the surface vegetation, starting with freshwater perennial grasses, including Hymenachne and Phragmites, then turning to the less palatable but more abundant Paspalum distichum L., a salt-tolerant grass which stabilizes tidal levees and is key in preventing the formation of saltwater bearing channels (Petty et al. 2005).

Channel formation rates were correlated with signs of buffalo impact on the South Alligator floodplain (Fig. 5c). The denuded floodplain surface was scoured by freshwater draining off the floodplains at the end of the wet season. This created channels that connected freshwater floodplains directly to tide-bearing channels. These channels directly and substantially impacted floodplain ecology by permitting the influx of tidal water to regions of salt-intolerant vegetation, and permitting early drainage of impounded freshwater, thus leading to early drying of floodplains in the dry season (Finlayson et al. 1997), and increased subsoil salinity (Stocker 1972). High sediment loads carried by incoming tides also filled in permanent freshwater lakes as has occurred on at least two occasions on the South Alligator River floodplain (Petty et al. 2005). The aerial photographic record of the floodplains of the East Alligator and South Alligator Rivers indicates severe and widespread vegetation loss, buffalo tracks, and a marked increase in channel formation after 1950 (Heerdegen and Hill 1999, Petty et al. 2005).

From 1950 to 1975 , there was a general decline in woody vegetation on the central floodplains: a notable exception being the eastern side of the South Alligator River where there was more active buffalo management (Fig. 5b). Data on the direct impact of buffalo on woody vegetation of the floodplains has not been reported, although there are numerous photographic records (e.g., Fig. 6; Letts et al. 1979), as well as reports of buffalo eating the seedlings and saplings of the shrub Cathormion umbellatum (Vahl) Kosterm (Lucas and RussellSmith 1993). Similarly, contrasting aerial photographs inside and outside of the current buffalo farm (central sector) show a marked decline in woody vegetation inside the boundary of the farm where buffalo graze (Riley 2005; Fig. 6a). In every case, photographic records and other studies show a negative relationship between woody vegetation and buffalo grazing.

The capacity of buffalo to browse and otherwise inhibit the growth of woody vegetation on floodplains contrasts with widely reported cattle mediated woody thickening, including recent findings in the Victoria River District (VRD), approximately $400 \mathrm{~km}$ southeast of the Alligator Rivers Region (Sharp and Whittaker 2003). On both the VRD and KNP, grazing significantly reduced fuel loads. On the VRD, however, woody cover in seasonally-inundated pastures increased with cattle grazing due primarily to the growth of Eucalyptus microtheca F. Muell. and Exoecaria parvifolia Muell. Arg. On the South Alligator River, where those species are absent but Melaleuca spp., as well as several shrubs 
(Cathormion umbellatum, Barringtonia acutangula (L.) Gaertn., and Strychnos lucida R. Br.) are prominent, woody thickening did not occur. Instead, in the South Alligator floodplains all vegetation decreased with buffalo grazing.

As elsewhere in KNP, the ecological impact of buffalo interacted strongly with fire. Prior to European settlement, these floodplains were a rich resource for Aboriginal people who would have burnt the floodplains extensively (Jones 1980, Haynes 1985, Meehan 1991, Lucas and Russell-Smith 1993). The arrival of buffalo in the region coincided with European settlement and Aboriginal depopulation and hence a decrease in both human sources of ignition and fuel loads. During the peak buffalo period "burning in many floodplain situations was no longer practicable" (Lucas and Russell-Smith 1993). However, once buffalo were removed, traditional fire regimes were not resumed on the depopulated floodplain.

There is little from the literature to inform us on the impact of buffalo on native floodplain fauna. Reports of long term Aboriginal and European residents of the area indicate that Magpie Geese (Anseranas semipalmata Latham) numbers declined in the South Alligator floodplains during the buffalo era (Frith and Davies 1961, Tulloch and McKean 1983, Lucas and RussellSmith 1993), due in part to widespread habitat destruction from buffalo grazing and wallowing (Corbett and Hertog 1996) and saltwater intrusion onto freshwater floodplains (Petty et al. 2005). The dusky rat (Rattus colletti Thomas) and other small vertebrates appear to be negatively impacted by buffalo, mainly through reduced vegetation cover at high buffalo densities (Friend et al. 1988).

Second cascade: buffalo eradication.-The hydrology of the floodplains appears to have largely recovered from the era of peak buffalo impact. Following buffalo removal in the region of the Woolwonga reserve in the 1970s, infilling by tidal sediment caused a marked contraction in channels within the South Alligator floodplain (Fig. 5a). Tidal sediments were stabilized by the re-establishment of freshwater and saltwater grasses across the floodplain, with the exception of Phragmites, which has yet to re-establish (Petty et al. 2005).

The total biomass of both herbaceous and woody vegetation on the floodplains increased with the removal of buffalo grazing (Petty et al. 2005; Fig. 5b). Relative abundances of herbaceous species also shifted very rapidly (Minchin and Dunlop 1989). For example, on the South Alligator floodplain in the northern sector, the grass Hymenachne acutigluma increased from 1984 to 1988, which in turn increasingly displaced the deep water spike-rush Eleocharis dulcis (Burm.f.) Trin. ex Hensch (Corbett and Hertog 1996). This result is comparable to the marked increase in total biomass and the relative increase in Paspalum distichum over grazing tolerant perennial herbs when Asian buffalo were removed from Keoladeo National Park in India (Vandervalk et al. 1993).

However, further changes in relative species abundances, especially among woody plants, were most likely confounded by the fire regime that followed buffalo removal (Table 1). Although fuel loads increased rapidly, historical fire regimes were not restored due to the fact that the original ignition source (independent bands of humans) was not replaced. Because of the greater availability of fuel, fires did become more extensive after buffalo were removed (Russell-Smith et al. 1997). Gill et al. (2000) reported a gradual increase in area burnt on floodplains from 5 million ha in 1980 to approximately 9 million ha in 1992. Nevertheless, fires were not frequent enough to prevent reestablishment of floodplain shrubs (principally Barringtonia acutangula, Cathormion umbellatum, and Strychnos lucida). These shrubs increased sharply in aerial cover and now exceed that found before the buffalo population eruption (Fig. $5 b$ ). We postulate that the subsequent change in fire regime, from traditional aboriginal fires to parkmanagement fires, has also played a role in any expansion of woody vegetation on the KNP floodplains once buffalo were removed.

Upon removal of buffalo, the nests of Magpie Geese shifted toward deep water areas at the edge of the floodplains (Corbett and Hertog 1996) and the numbers of the native dusky rat increased (Skeat et al. 1996). Feral pig populations increased at least 3-fold across the region, due to release from competition with buffalo (Corbett 1995). In general, the removal of buffalo on the Kapalga floodplains initiated a cascade of events (Table 1) with detectible changes in vegetation within one year, in small herbivores within two years, and in small predators within three years (J. A. Taylor et al., personal communication).

\section{Monsoon rain forests}

Monsoon rain forests are evergreen, closed-canopy forests; non-Eucalypt, fire-sensitive species are the dominant woody species (Bowman 2000). In the Alligator Rivers region, they occur as an archipelago of hundreds of small fragmented patches and as such are particularly vulnerable to disturbance (Russell-Smith and Dunlop 1987, Bowman 2000). Buffalo frequently rest and camp in these densely wooded, closed-canopy areas, often as preferred habitat (Tulloch 1978, Taylor and Friend 1984), and so their density in monsoon rain forest can be much higher than that of the surrounding landscape (Ridpath 1991). Ecological impacts ranged from severe to relatively undisturbed, varying from patch to patch depending upon the landscape setting, but always correlated to buffalo densities.

Although research on the mechanisms of buffalo impacts on monsoon rain forests is sparse, within the patches of monsoon rain forest themselves most of the impact appears to be due to the direct effects of buffalo activity: soil and root compaction, browsing, wallowing 
TABLE 1. Summary of impacts of the two buffalo-mediated cascades on floodplain, rain forest, and woodland vegetation types.

\begin{tabular}{|c|c|c|}
\hline $\begin{array}{l}\text { Location and } \\
\text { component }\end{array}$ & Cascade 1: 1960-1985 & Cascade 2: 1985-present \\
\hline \multicolumn{3}{|l|}{ Floodplain } \\
\hline Driver & $\begin{array}{l}\text { Increased grazing pressure on grasses. Trampling and } \\
\text { compaction of soils and physical damage to woody } \\
\text { vegetation. }\end{array}$ & $\begin{array}{l}\text { Increased fuel loads with release from grazing } \\
\text { pressure, but decreased ignition due to human } \\
\text { depopulation. }\end{array}$ \\
\hline Principal effects & $\begin{array}{l}\text { Decreased woody and grass cover. Rapid increase in } \\
\text { saltwater bearing channels. Loss of some } \\
\text { freshwater vegetation communities, siltation of } \\
\text { some ponds. }\end{array}$ & $\begin{array}{l}\text { Increase in woody cover. Grass cover largely } \\
\text { restored although not some species (e.g., } \\
\text { Phragmites karka). Channels restabilized. }\end{array}$ \\
\hline \multicolumn{3}{|l|}{ Rain forest } \\
\hline Driver & $\begin{array}{l}\text { Trampling and compaction of soils. Grazing pressure } \\
\text { on grasses at rain forest boundary. }\end{array}$ & $\begin{array}{l}\text { Increased fuel loads are managed by protective } \\
\text { burning at rain forest margins. }\end{array}$ \\
\hline Principal effects & $\begin{array}{l}\text { Understory cover reduced in interior. Increased } \\
\text { invasion by native and exotic herbs at rain forest } \\
\text { boundary and interior. Reduction of grass fuels at } \\
\text { forest boundary may have caused expansion of } \\
\text { forest edge due to reduced fire intensity. }\end{array}$ & $\begin{array}{l}\text { Apart from exotic weed legacy, buffalo removal is } \\
\text { unlikely to have had significant impact on } \\
\text { continued rain forest expansion. }\end{array}$ \\
\hline \multicolumn{3}{|l|}{ Woodland } \\
\hline Driver & $\begin{array}{l}\text { Increased grazing pressure on grasses and, to a lesser } \\
\text { degree, woody juveniles. }\end{array}$ & $\begin{array}{l}\text { Release of ground vegetation, particularly } \\
\text { annuals initially, with perennials coming later. } \\
\text { High fire frequency promotes annual sorghum. }\end{array}$ \\
\hline Principal effects & $\begin{array}{l}\text { Decreased total ground vegetation and a shift to } \\
\text { annuals. Reduced intraspecific competition and } \\
\text { lower fuel loads result in increased growth and } \\
\text { lower mortality in woody species. }\end{array}$ & $\begin{array}{l}\text { Increased competition with understory reduces } \\
\text { growth and survival of woody plants. More } \\
\text { frequent and intense fires lead to increased } \\
\text { mortality in juvenile woody species. }\end{array}$ \\
\hline
\end{tabular}

Note: Cascade 1 corresponds to rapid buffalo population increase, while cascade 2 follows the elimination of buffalo through a deliberate eradication campaign.

and physical destruction of vegetation (Braithwaite et al. 1984, Russell-Smith and Dunlop 1987, Russell-Smith and Bowman 1992; Table 1). Russell-Smith (1984) showed that in sandstone terrain, only those rain forest sites associated with springs or streamline habitats were seriously affected by buffalo, while in the lowlands, impact was widespread. The general pattern of impact in the sandstone springs was destruction of margin vegetation by wallowing, and erosion leading to tree death. In lowland habitat types, Russell-Smith (1984) found that the most obvious impact was the elimination of the lower strata of woody plants as well as the death of canopy trees. This is consistent with the impacts recorded by Braithwaite et al. (1984), who sampled 30 monsoon rain forest patches in KNP and compared sites with varying intensity of use by buffalo. They concluded that buffalo had a fundamental impact on vegetation structure and composition, including reduced lower canopy cover, and postulated that soil compaction by buffalo caused the death of large trees by hindering groundwater recharge. The density of vegetation under 3 $\mathrm{m}$ height was negatively related to buffalo density in the dry season although weedy annual species, particularly Hyptis suaveolens (L.) Poit. (see Plate 1) and Cassia spp., increased with buffalo presence (Braithwaite et al. 1984, Cowie and Werner 1993).

Secondary effects of the type found in floodplains or savanna woodlands have not been examined other than those related to fire. Changes in fuel loads at the periphery of rain forests, due to buffalo grazing and wallowing, in turn affect fire regimes. Any changes in peripheral fire regime can affect the boundaries of the monsoon rain forest patches and/or penetrate into the interior of the forest; there are examples of both increases and decreases of patch sizes.

Although there has been some localized contraction due to buffalo impact and introduced weeds, overall there is clear evidence from aerial photography that most patches of monsoon rain forest have expanded in Kakadu National Park (Banfai and Bowman 2006). Reduced fire frequency surrounding monsoon rain forest patches has been implicated as a major cause of monsoon forest expansion elsewhere (Hopkins 1992, Swaine et al. 1992, King et al. 1997, Bowman et al. 2001). Although buffalo may have played a role in this recent expansion, it is unlikely that they were the primary and/or only driver as there was little evidence of a change in the rate of expansion during the peak period of buffalo populations in the 1970s, or following the dramatic reduction in buffalo numbers in the $1980 \mathrm{~s}$ (Banfai and Bowman 2006).

The apparent contradictory nature of buffalo impact on monsoon rain forests can be partially resolved by separating their impact on forest interiors (mediated by behaviors such as grazing and trampling) from forest boundaries (mediated by their indirect impact on fire regimes). Buffalo appear to contribute substantially to the structural decline of forest interiors through grazing, trampling, and acting as weed vectors. On forest boundaries their impact is more mixed. Buffalo promote the expansion of monsoon rain forest boundaries by reducing fuel loads outside of monsoon rain forests and 


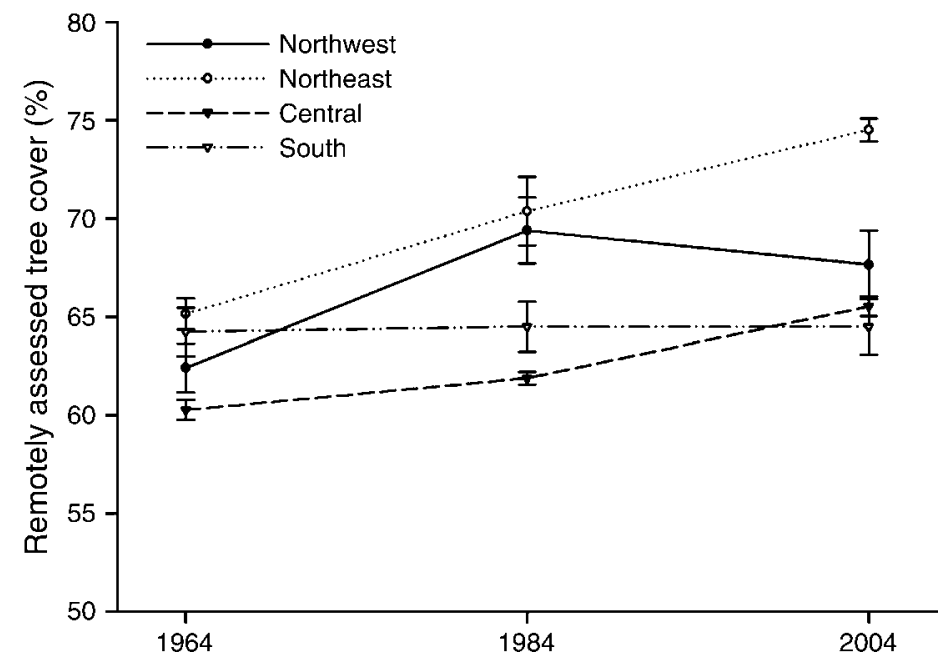

FIG. 7. Trajectories of change in tree cover by sector from 1964 to 2004 . For comparison, the northern sector is divided into west of the South Alligator River (northwest SA) and east of the South Alligator River (northeast SA). Error bars indicate \pm SE. The data are from Lehmann (2007).

hence the severity of fires which might impact on rain forest boundaries. At the same time, buffalo also promote rain forest contraction by allowing grass establishment and weed invasion in gaps (as more canopy trees die with buffalo present) and creating buffalo thoroughfares through the vegetation, both of which permit greater fire penetration into the interior of rain forest patches. Such "fire tongues" along buffalo tracks have been observed at several sites in KNP (Russell-Smith 1984).

The long-term legacy of the buffalo era seems to be increased weed populations along rain forest margins. Otherwise, there is no known evidence of a "second cascade" phenomenon within monsoon rain forests.

\section{Savanna woodlands and open forest}

Eucalypt-dominated woodland and open forest cover over $60 \%$ of the Alligator Rivers Region (ARR) (Wilson et al. 1996; Fig. 2b). Unfortunately, little has been published on the impact of introduced buffalo on the drier upland woodlands, despite clear evidence that buffalo used these areas extensively and floodplains and woodlands are intricately tied with regard to buffalo life histories (Tulloch 1969, 1970, 1978, Tulloch and Cellier 1986, Werner 2005).

Buffalo are broad-spectrum grazers whose grazing patterns are strongly determined by grass phenology, not necessarily relative abundance or even nutrition (Tulloch 1970, Tulloch and Cellier 1986). During the wet season, when the flood plains are inundated, buffalo eat underwater vegetation in the shallower areas, retreating to the upland savanna woodlands for nurseries and overnight camps and grazing of newly germinated annual grasses in the woodlands. At the end of the wet season, as the floodplains dry out, the newly exposed sedges and grasses there become a major food source for buffalo. In the latter part of the dry season when floodplains are no longer lush, buffalo again rely heavily on the savanna woodlands, although this time most of the annuals are senescent, and buffalo graze perennial grasses.

Given these daily and seasonal movements, population densities of buffalo in woodlands would have exceeded those on the floodplain at certain times of day and seasons. In the early 1980s, at peak population numbers, the mean density of buffalo in the woodlands of the northern sector was estimated at 7 animals $/ \mathrm{km}^{2}$ in Munmarlary (Bowman et al. 1988) and a substantial 15 animals $/ \mathrm{km}^{2}$ at the Kapalga Research Station (Ridpath et al. 1983, Ridpath 1991).

Most of what is known about the impact of buffalo on upland wooded savannas comes from two bodies of research, which we integrate in this section:

1) A landscape scale field experiment from 1981 to 1989 conducted by CSIRO, wherein buffalo were excluded from the southern half of the $700-\mathrm{km}^{2}$ site at Kapalga in the northern sector of KNP, and comparisons made with the northern half where buffalo remained. Annual monitoring of flora and fauna yielded insights on mechanisms of changes to savanna woodland ecosystems attributable to buffalo (Friend and Taylor 1984, Taylor and Friend 1984, Werner 1986, 2005, Werner and Murphy 1987, Ridpath and Waithman 1988, Minchin and Dunlop 1989, Hodda 1992, Corbett 1995, Corbett and Hertog 1996, Skeat et al. 1996, Werner et al. 2006).

2) Broad field surveys and analysis of aerial photographs of sites covering all sectors of KNP (Lehmann 2007). The aerial photographic analysis covered the period from 1964 to 1984 (when buffalo numbers rapidly increased) and from 1984 to 2004 (when buffalo numbers rapidly decreased). Patterns of demography and recruitment were also investigated by ground surveys of vegetation on these same sites in 2003-2004 (Lehmann 2007).

First cascade: buffalo population eruption.-The only direct evidence of vegetation changes in woodlands during the period of rapid increase in buffalo densities is 
the photographic record, where Lehmann (2007) compared woody cover in 1964 and 1984. This shows a general trend of increased woody cover, with some differences among sectors of KNP (Fig. 7). Increases in tree cover can be the result of increased recruitment of new trees and/or the enlargement of established trees. Insights into the degree that each of these and other changes in the understory may be important, as well as the mechanisms of these changes, have been gleaned from experimental work in buffalo-absent and buffalopresent plots during the second cascade.

In 1982, the frequency size distributions of tree populations in Kapalga showed a bias toward middle and large trees: in six study plots spread over a topographic gradient, there were no trees $<5 \mathrm{~cm}$ diameter breast height (dbh) and fewer juvenile trees $(<1.4 \mathrm{~m}$ height $)$ and trees $<20 \mathrm{~cm}$ dbh than expected in a stable population (Werner 1986). From size-specific growth rates, it was estimated that there had been almost no recruitment of juveniles into the sapling stage for approximately 20 years prior to 1982: a time period that coincides with the buffalo eruption (Werner and Murphy 1987). Further, the results of a nine-year, longitudinal study of individually marked trees showed that both the growth and survival of established trees were significantly enhanced in the presence of buffalo (but no fire), but that recruitment into the canopy was negligible (Werner 2005).

Experimental studies have shown that the direct effect of buffalo on woodlands was to reduce herbaceous vegetation (mainly grasses) which in turn enhanced the growth and survival of established trees of all sizes (Table 1). Competition for water among grasses, juvenile plants and canopy trees is very strong in the top $50 \mathrm{~cm}$ of the soil during the early dry season (Chen et al. 2004). The dense herds of buffalo in woodlands at Kapalga removed an estimated $2-6 \mathrm{Mg} /$ ha of herbaceous biomass per year through grazing and trampling (Fig. 8). In a six-year experimental study (1983-1988) of marked juvenile $(<1.4 \mathrm{~m}$ height $)$ trees at Kapalga juveniles grew significantly faster and had significantly higher survival rates in the presence of buffalo (and no fire), despite the fact that $10-12 \%$ of them showed signs of mammalian herbivory, compared to only $0-1 \%$ where buffalo had been removed (Werner et al. 2006). Similarly, in a concurrent eight-year study (1982-1989) of 750 marked established trees on the same site, all trees had higher growth rates and lower mortality rates in the presence of buffalo (no fire), and only the late season fires affected them adversely (Werner 2005). Indeed, the growth and survival of established adult and juvenile trees have been enhanced by the removal of herbaceous vegetation by a variety of means, including buffalo grazing, experimental hand clipping, early dry season fires (Werner 2005, Werner et al. 2006), and even poor rainfall years (Prior et al. 2006).

In spite of the advantages in growth and survival of established trees in the presence of buffalo, however,

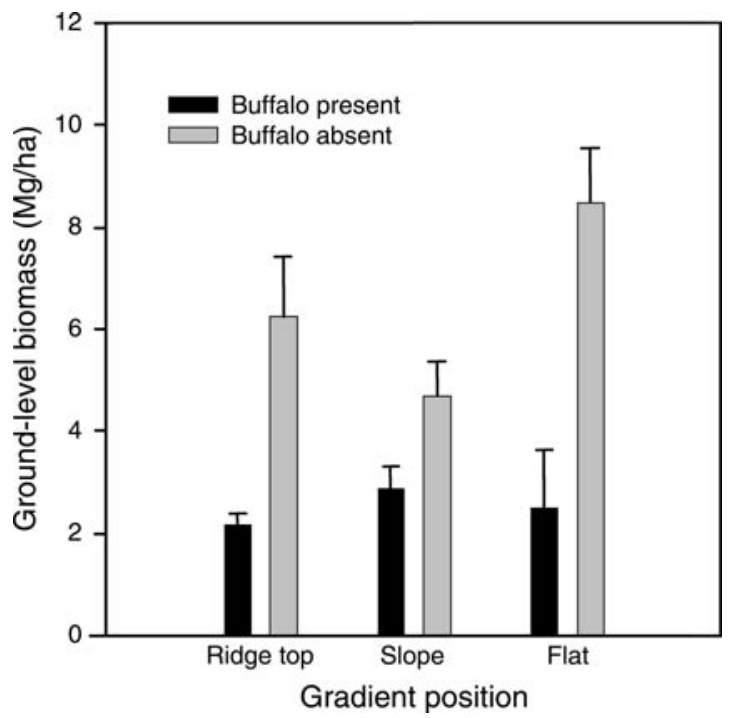

FIG. 8. Mean total ground-level biomass in paired plots of woodland, with buffalo present (solid bars) and buffalo removed (gray bars), on the ridge top, slope, and flat, at the end of the growing season three years after buffalo were removed, and without any intervening fires. Histogram bars show means; error bars on means indicate +2 SE. The figure is from Werner (2005), used with permission.

there was a recruitment bottleneck where juvenile eucalypts did not move into the sapling sizes (Werner et al. 2006). The most likely explanation is that overstory competition was sufficient to prevent juvenile Eucalypts from moving into sapling stages (Fensham and Bowman 1992). Juvenile eucalypts are particularly susceptible to water stress (Prior et al. 1997). Such was not the case for species of mid-storey non-eucalypts, however, wherein populations doubled to quadrupled from 1982 to 1990 where buffalo were present, but declined where buffalo had been removed (Werner 2005). Fire was also particularly damaging to juvenile trees where buffalo had been removed, due to increased fuel loads (Fig. 9).

Using aerial photographs of wooded savanna in the Kapalga section, in the western side of the northern sector, Lehmann (2007) found that total tree cover increased from 1964 to 1984, but then decreased thereafter (Fig. 7). This is consistent with the demographic shift where the lowered recruitment of juveniles to adults results in the long-term decrease in the number of adults in the overstory. By contrast, on the eastern side of the South Alligator River (edaphically identical to the western side, but with historically lower buffalo numbers), and in the central sector of KNP, tree cover increased over the entire period from 1964 to 2004 (Fig. 7).

In the southern sector, there has been no change in the average woody cover over the past 40 years (Fig. 7), although there has been dynamic change at local scales. This is true despite clearly having buffalo densities nearly as great as the central sector (Fig. 4) and evidence of buffalo impact on soil erosion and understory 


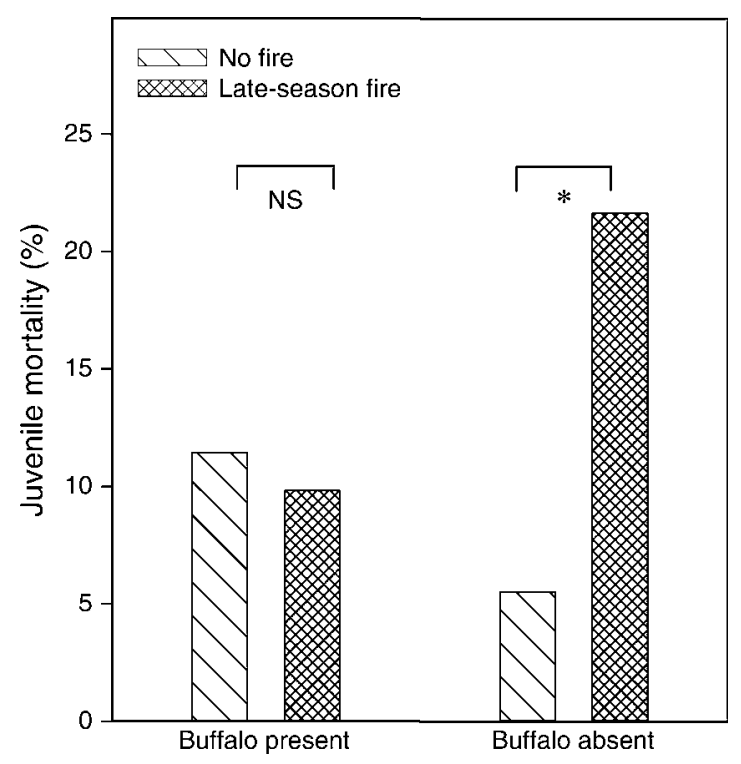

FIG. 9. Mortality of juvenile trees in savanna woodland in buffalo-present vs. buffalo-absent plots, averaged across all time intervals over the six years of the experiment, in plots that received no fire vs. in plots that received high-intensity, lateseason fires. The figure is from Werner et al. (2006), used with permission.

vegetation (East 1990, Skeat et al. 1996). Similarly, Sharp and Bowman (2004) found little change in upland savanna woodlands in cattle grazed areas of the Victoria River District (VRD). Both the VRD and the southern sector of KNP are xeric relative to the northern sector of KNP (Fig. 2c). Rainfall in the southern sector lies close to the annual water use requirements for Eucalyptus woodland (Hutley et al. 2000), which, given the high interannual variation in rainfall in the Top End, makes the southern KNP savanna woodlands particularly vulnerable to severe stress during dry years. Higgins et al. (2000) have suggested that more xeric systems have less capacity for large variance in the fire regime, and correspondingly, for grazing impacts on fire regime. To the extent that Higgins et al.'s (2000) suggestion holds across small gradients (e.g., a difference of $250 \mathrm{~mm} / \mathrm{yr}$, north to south, in KNP), it may be that in the southern sector of KNP, rainfall plays a much larger role relative to fire and/or grazing in defining tree/grass coexistence, as has been found in other xeric savanna systems (Sankaran et al. 2005).

Buffalo shifted the relative proportion of annual and perennial herbaceous plants in favor of the former (Minchin and Dunlop 1989; unpublished data discussed in Skeat et al. 1996). This had significant consequences once buffalo were removed from this system due mainly to hysteresis effects of grasses, and hence fire regime. Further, Hodda (1992), in a survey of termites in Kapalga, found that the decrease in total herbaceous vegetation and the relative shift to annual grasses negatively affected "harvester" termites which preferentially feed on perennial grasses. Conversely, the species richness and abundance of termites that feed on the wood of live trees or forage in wood litter (and on buffalo dung) were positively correlated with buffalo presence (Braithwaite et al. 1988, Hodda 1992).

Second cascade: buffalo eradication.-The second ecological cascade was driven by an ecological "rebound" of the herbaceous vegetation (Werner 2005, Werner et al. 2006): a temporary but very large increase in primary production common during secondary succession (Horn 1974). In Kapalga, biomass more than doubled within three years (Fig. 8). In locations where both buffalo and fire were removed from the system, biomass increased several fold to a steady state in three to six years (Cook 2003). Most of the large increase in biomass was due to an immediate increase in annual grasses. Only later did perennial grasses become a significant part of the understory, through competitive advantage, but only if an area was left unburned and ungrazed for three to eight years or more. Perennial grass cover increased the longer a site was left unburned, but never rose above an average of $26 \%$ during the study period (P. A. Werner and J. S. Cusack, unpublished data). In general, annual grasses dominate stands that are continuously burned or grazed.

By far the most abundant annual grass in woodlands is the native annual sorghum (Sorghum intrans $\mathrm{F}$. Mueller ex Benth). The removal of buffalo is widely perceived as the driver of an overall increase in native annual sorghum across KNP within the last decade (Miles 2003). To a great extent, this is true, as buffalo selectively grazed perennials to the advantage of annuals such as sorghum, and certainly fostered its dominance in the region. But this view must be blended with other observations on the role of fire since buffalo removal, as sorghum is fire promoting and fire dependent (Cook et al. 1996) and the abundance of sorghum is strongly associated with fire frequency (Elliott 2005; Bowman et al., in press). The sorghum dominated understory is now heavily entangled with increasing fire frequencies in KNP, where the mean fire frequency in woodland has increased from $55 \%$ to $70 \%$ in the past decade (Bowman et al., in press; Petty and Bowman, in press).

These shifts in biomass and species composition of herbaceous vegetation had set the stage. What happened next to woodland structure depended mainly on fire treatments once buffalo were removed. In KNP, the woodlands were burned by both park managers and Aboriginal residents, resulting in fire-return intervals of one to two years (Price et al. 2005). Starting around 1984, fires tended to occur earlier in the dry season (Russell-Smith et al. 1997), perhaps in part because annual grasses, particularly sorghum, cure earlier than most perennial grasses, thus permitting earlier fires. Woodland areas of Kapalga (northern sector) where buffalo had been removed for some nine years, and fire excluded for three years after removal, had an abun- 
dance of eucalypt juveniles and saplings (Prior et al. 2006). This is in contrast to areas of Kapalga that had been burned annually from 1990 to 2003, following buffalo removal. Here the woodland remained dominated by an understory of annual sorghum with few sapling trees, and the eucalypt canopy cover had declined by more than half (Werner 2005; P. A. Werner, unpublished data).

Without fires, marked trees in experimental plots in Kapalga had lower growth and survival rates when buffalo were removed, compared to trees where buffalo still grazed (Werner 2005, Werner et al. 2006). After late dry-season fires, however, growth rates of established eucalypts in plots where buffalo had been removed did not return to unburned levels over the next two years, whereas they did where buffalo grazed (Werner 2005). Juvenile mortality was $22 \%$ in burned plots and $6 \%$ in unburned plots where buffalo had been removed, but there was no statistical difference with respect to fire where buffalo continued to graze (Werner et al. 2006; Fig. 9). The differences in responses to fire with buffalo removal are most probably linked to the differences in understory vegetation, and hence fuel loads.

In a 2005 survey of woodland stand structure throughout KNP, Lehmann (2007) found that sapling recruitment into the overstory was limited by fire as well as basal area. However, beyond speculating on the effect of increasing fire frequency and intensity due to increasing annual grasses during the second cascade as well as increases in basal area during the first cascade, the degree to which buffalo removal has played a role in limiting sapling recruitment across Kakadu is not known.

\section{Discussion}

\section{Resistance and resilience of KNP vegetation types}

The stability of ecosystems within a given ecological state has two aspects: resistance, the capacity of a system to resist change, and resilience, the capacity of a system to recover to a prior state after change (Westoby et al. 1989, Suding et al. 2004). Evolutionary history can have a profound impact on stability as evidenced by savanna grasses in Africa which seem to be resilient to grazing (McNaughton 1985). In contrast, perennial savanna grasses in northern Australia appear to have low resilience to sustained grazing pressure by introduced ungulates, as evidenced by the deliberate introduction of African perennial grasses into Australian pastures (Tothill and Mott 1985b, Winter 1991). Additionally, as we illustrate here, native perennial grasses are reduced in favor of highly flammable native annual grasses where large grazers are present. This low resilience of Australian perennial grasses to grazing by large herbivores is most likely due to evolutionary history (Ridpath et al. 1993).

Resistance and resilience differ with vegetation type in KNP. Floodplain systems exhibit low resistance to change-rapid changes in grass species composition, reduction in grass cover, and expansion of channels under high buffalo population densities (Knighton et al. 1992, Finlayson et al. 1997, Petty et al. 2005) _ but high resilience in returning to the previous state-rapid increase in grass cover, recovery of most floral assemblages, and reduction of channels after buffalo removal (Fig. 10b; Finlayson et al. 1997, Petty et al. 2005).

In the monsoon rain forests, overstory cover in the interior of rain forest patches is quite resistant to change, perhaps due in part to the long life spans of most dominant rain forest tree species, as well as some protection from disturbance (Fig. 10a). Within the monsoon rain forest stands understory dynamics are unknown, although it is clear that buffalo caused extensive damage (Braithwaite et al. 1984, Lucas and Russell-Smith 1993), but recovery has not been assessed. On monsoon rain forest boundaries, park managers have aimed to reduce fire frequency to counter the effects of increased fuel loads with the removal of buffalo, and may have played a major role in increasing the total rain forest cover in the park (Banfai and Bowman 2006).

Woodlands are highly resistant to change, at least initially. However, high resistance is accompanied by low resilience, due in part to changes in the understory that prevent the recruitment of young canopy trees, both due to hysteresis effects from buffalo removal and from subsequent fire management. Indeed, the changes documented over the past 40 years indicate a shift in some areas to an alternate "grass-fire" state in woodlands where the understory is dominated by annual sorghum, increased fire frequencies, and, potentially, a long-term decrease in woody cover (Fig. 10a).

The magnitude of change is different depending on historical buffalo population levels. Most of the evidence for buffalo-caused inhibition of overstory recruitment, post-buffalo release of annual sorghum, and juvenile tree/sorghum interactions comes from experiments performed on the western side of the South Alligator River, the region of KNP that historically had the highest buffalo populations. As if to underscore the role of buffalo in any state shift, we do not see a decline in overstory cover on the eastern side of the South Alligator where buffalo population levels were historically lower. By contrast, in the southern sector of KNP, where buffalo numbers were historically lower, there was little change overall. However, this must be tempered by consideration of likely lower carrying capacity in the less productive South, as well as the possibility that lower rainfall makes Southern savannas even more resistant (Sankaran et al. 2005; Fig. 10b). Unfortunately, little is known of recruitment patterns or understory vegetation dynamics in the southern sector, and it is difficult to make definitive conclusions at this time. 
a) Mesic woodland (north sector)

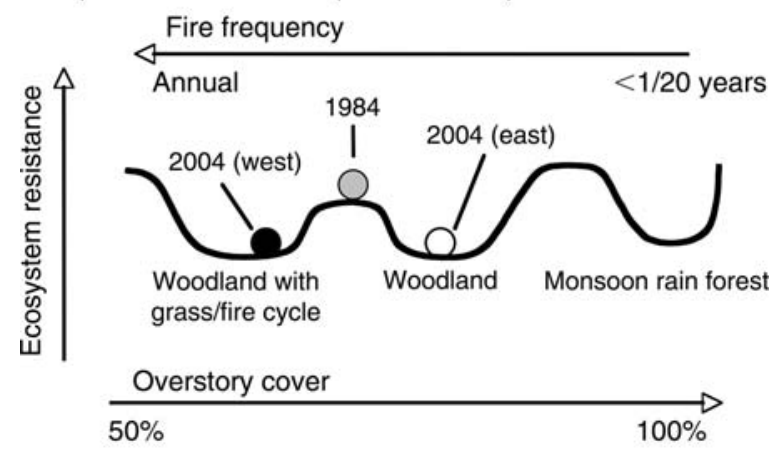

b) Central sector floodplains

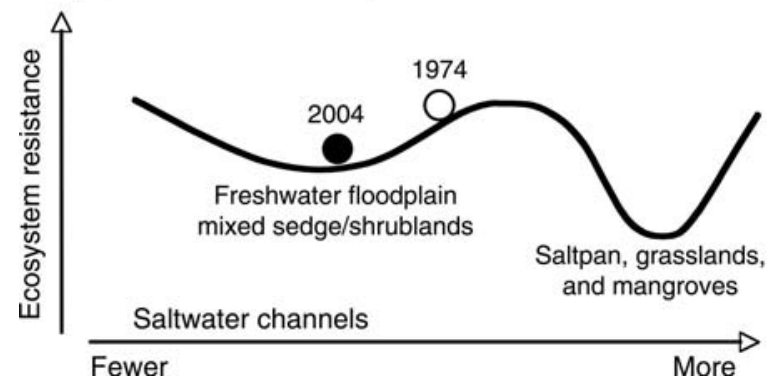

FIG. 10. Conceptual models illustrating resistance and resilience within savanna ecosystems in KNP. Resistance refers to the strength of feedback loops that prevent change in the system; resilience refers to the ability of a system to return to a previous state once disturbed. (a) This panel illustrates high resistance but low resilience in the mesic savanna woodlands and rain forests of the northern sector. The savanna woodlands have been quite resistant to change, but as illustrated by the divergence of the west and east portions, the systems are less likely to return to their previous stage once disturbed. The west portion, in particular, seems to have entered a state where the understory is dominated by annual sorghum, and recruitment of new trees continues to be inhibited by high fire frequencies and fuel loads (a grass/fire cycle). Conversely, in the eastern portion, where fires occurred less frequently from at least 1975 to 1990 , the canopy continues to increase, and there is a more even mix of annual and perennial species in the understory. The monsoon rain forest is a non-disturbance-dependent climax community; in areas with deep soils, a very long fire-free interval could drive woodland communities to a monsoon rain forest state, while in other areas, overall cover and relative abundance of some rain forest species would increase (Woinarski et al. 2004). (b) This panel illustrates the low resistance but high resilience of the freshwater floodplains of the tidal region of the central sector. Floodplains have changed rapidly under impact from buffalo grazing (low resistance) toward a highly resistant state where sediment deposition is no longer able to counteract incoming tidal force and the floodplains are dominated by extensive saltwater marshes and mangrove channels. Such a state did exist under higher sea level conditions 7000-5000 yr BP (Woodroffe et al. 1985). Following buffalo removal, the floodplains are quickly returning to historical equilibrium (high resilience).

\section{Long-term consequences and management}

KNP is internationally renowned as simultaneously a pristine landscape and a landscape culturally constructed by Aboriginal people who continue to live in the park. However, continued management of the region requires the recognition of European settler efforts to "domesticate" this area of the frontier; efforts that were both facilitated and hampered by buffalo (Robinson 2005). Successful future management decisions for KNP and the Top End as a whole require an understanding of the characteristics of the present ecosystem in relation to the pre-buffalo "reference ecosystem" (sensu Egan and Howell 2001), as well as the consideration of means to manage the long term effects of buffalo removal.

Today, feral buffalo are once again dispersing into KNP and continue to grow in numbers in neighboring Arnhem Land. They have reached particularly high population densities in the vicinity of the Blythe River and the Arafura Swamp in central Arnhem Land, a wetland complex as extensive as the Alligator Rivers region. The long term prospects for controlling buffalo across a wide landscape are currently unknown and it is very possible that increasing feral buffalo populations will become a significant factor in KNP and beyond, and perhaps in KNP initiate a "third ecological cascade."

Bond and Keeley (2005) have drawn parallels between fire and herbivores as alternative consumers of vegetation. Although grazing doesn't necessarily replicate fire in terms of behavior or pattern, we show multiple examples in this paper where both are equally effective at consuming herbaceous biomass. Historically, most studies of mesic savannas have focused on grazing effects alone (with a vast literature on African savannas, Bond and Keeley 2005). Alternatively, empirical studies of fire and/or edaphic factors rarely address how grazing may have played a role in the vegetation dynamics of mesic savannas (e.g., Menaut et al. 1990, Lonsdale and Braithwaite 1991, Swaine et al. 1992, Bowman and Panton 1993, Glitzenstein et al. 1995, Williams et al. 1998, 1999, 2002, Moreira 2000, Andersen et al. 2003, Gardner 2006), although Russell-Smith et al. (2003) mention that buffalo may have played a role in interpreting a 24-year study of the effects of fire on savanna woodland in KNP. The general lack of consideration for grazing in fire studies is perhaps understandable because fire effects are immediate and dramatic, grazers may no longer be present, and the impact of hysteresis effects can be easily overlooked or underestimated without a historical perspective. Notable exceptions are studies of Norton-Griffiths (1979), McNaughton (1993), and Mills and Fey (2005) on interactions between fire and native large grazers in Africa, and the studies of Silva et al. (2001) and San José and Fariñas $(1983,1991)$ on changes in a cattle- and fireprotected savanna in Venezuela. In general, our study shows consistency with the African studies, but comparisons with the Venezuelan work are inconclusive.

The results of this KNP study are consistent with models of fire-grazer interactions in savannas developed from an east African perspective (Higgins et al. 2000, van Langevelde et al. 2003, Archibald et al. 2005) as well as field studies in drier savannas of northern Australia 
(Fensham and Skull 1999, Sharp and Whittaker 2003, Sharp and Bowman 2004). Further, both time lags and rainfall gradients in KNP show a similar pattern of change to that reported along a rainfall gradient in the Serengeti (Norton-Griffiths 1979). There Norton-Griffiths (1979) found a greater decline in woody vegetation from 1958 to 1972 in the wetter north, which he primarily attributed to a time lag from repressed recruitment due to intense fires during the rinderpest epidemic. As in KNP, grazer-induced changes in fire regime had less of an impact on woody cover in the drier southern regions of the Serengeti.

Still, however, the long-term cascading impact of grazing differs between Australia and Africa. The subsequent release in Australia of a fire-promoting native annual has created the possibility of a long term decline in the tall woody canopy (Fig. 10a). Globally, the savannas of the KNP (and ARR) are most analogous to the moist savannas of South America, particularly the cerrados of Brazil (Furley 1999), as neither supports populations of large native grazers. It would be of great interest, and immediate importance, to investigate the impact of introduced grazers on cerrados dynamics in South America.

Additionally, comparisons would be fruitful with the Amazonian floodplains of Brazil, which currently have the highest rate of buffalo population growth in the world (Sheikh et al. 2006). The response of vegetation on the floodplains of Keoladeo National Park in India, where buffalo were removed from their native habitat, would also be informative. There, the floodplains contained a rich mixture of grazing-tolerant plant species when buffalo were present. The relative abundance of these species declined after buffalo were removed (Middleton et al. 1992).

Successful management of savanna ecosystems requires a thorough understanding of the historical range of variability in the system, the factors that drive that variability, and an understanding of potential alternate states. This is critical, not only for understanding the range of potential management targets, but also for understanding how best to manage savannas within desired thresholds (van Wilgen et al. 2004) as the importance of savannas to human economies increases in the next century.

\section{ACKNOWLEDGMENTS}

This project developed from a discussion group at the School for Environmental Research at Charles Darwin University focusing on the role of buffalo in structuring the vegetation of the Top End of Australia. We learned that many of the conflicting histories and results of our own and previous studies could be explained only by reconsideration of the historical ecology of the buffalo and social history of the settlers, and that they made sense only when we considered each geographic sector of Kakadu in its own right. Further, we realized that the "signature" of the buffalo was still strongly evident, some two decades after the eradication campaign to eliminate them. Such conclusions would have been impossible without the careful observations the "old timers"-Dave Lindner and Alan Fisher-graciously shared with us. We thank them and Terry
Hill and Rob Muller of KNP for their help in reconstructing the latter years of BTEC, Peter Bayliss who provided information on current distributions of buffalo in Kakadu, Jeremy Freeman for use of unpublished data on floodplain channels (Fig. 5), and J. W. Shirley, V. deKoninck, T. Stohlgren, and two anonymous referees for critical review of the manuscript. Funding for this work came in part from Kakadu National Park, Australian Research Council Discovery Grant 0343000 , and ARC Linkage Grant 0346929, as well as an Australian Postgraduate Awards (Industry) scholarship for C. Lehmann.

\section{Literature Cited}

Andersen, A. N., G. D. Cook, and R. J. Williams, editors. 2003. Fire in tropical savannas: the Kapalga experiment. SpringerVerlag, New York, New York, USA.

Archer, S. 1990. Development and stability of grass/woody mosaics in a subtropical savanna parkland, Texas, U. S. A. Journal of Biogeography 17:453-462.

Archibald, S., W. J. Bond, W. D. Stock, and D. H. K. Fairbanks. 2005. Shaping the landscape: Fire-grazer interactions in an African savanna. Ecological Applications 15:96109.

Banfai, D. S., and D. M. J. S. Bowman. 2006. Forty years of monsoon rainforest expansion in Kakadu National Park, northern Australia. Biological Conservation 131:553-565.

Bayliss, P., and K. M. Yeomans. 1989. Distribution and abundance of feral livestock in the "Top End" of the Northern Territory (1985-86), and their relation to population control. Australian Wildlife Research 16:651-676.

Belsky, A. J. 1990. Tree/grass ratios in East African savannas: a comparison of existing models. Journal of Biogeography 17: 483-489.

Bond, W. J., and J. E. Keeley. 2005. Fire as a global "herbivore": the ecology and evolution of flammable ecosystems. Trends in Ecology and Evolution 20:387-394.

Boulton, W. J., and W. J. Freeland. 1991. Models for the control of feral water buffalo (Bubalus bubalis) using constant levels of offtake and effort. Wildlife Research 18:63-73.

Bowman, D. M. J. S. 2000. Australian rainforests: islands of green in a land of fire. Cambridge University Press, Cambridge, UK.

Bowman, D. M. J. S., D. C. Franklin, O. F. Price, and B. W. Brook. In press. Land management affects grass biomass in the Eucalyptus tetrodonta savannas of monsoonal Australia. Austral Ecology.

Bowman, D. M. J. S., and W. J. Panton. 1993. Differences in the stand structure of Eucalyptus tetrodonta forests between Elcho Island and Gunn Point, Northern Australia. Australian Journal of Botany 43:211-215.

Bowman, D. M. J. S., A. Walsh, and D. J. Milne. 2001. Forest expansion and grassland contraction within a Eucalyptus savanna matrix between 1941 and 1994 at Litchfield National Park in the Australian monsoon tropics. Global Ecology and Biogeography 10:535-548.

Bowman, D. M. J. S., B. A. Wilson, and R. J. Hooper. 1988. Response of Eucalyptus forest and woodland to four fire regimes at Munmarlary, Northern Territory, Australia. Journal of Ecology 76:215-232.

Braithwaite, R. W. 1990. Australia's unique biota: implications for ecological processes. Journal of Biogeography 31:207223.

Braithwaite, R. W., M. L. Dudzinski, M. G. Ridpath, and B. S. Parker. 1984. The impact of water buffalo on the monsoon forest ecosystem Kakadu National Park. Australian Journal of Ecology 9:309-322.

Braithwaite, R. W., L. Miller, and J. T. Wood. 1988. The structure of termite communities in the Australian tropics. Austral Ecology 13:375-391.

Braithwaite, R. W., and P. A. Werner. 1987. The biological significance of Kakadu National Park. Search 18:296-301. 
Carrington, L. 1885. Capt. Carrington's report on Alligator, Blyth, Liverpool and King Rivers, etc. Final Report Canberra, Port Darwin. Australian National Archives, Darwin, Australia.

Chen, X., D. Eamus, and L. B. Hutley. 2004. Seasonal patterns of fine-root productivity and turnover in a tropical savanna of northern Australia. Journal of Tropical Ecology 20:221224.

Chidumayo, E., J. Gambiza, and I. Grundy. 1996. Managing miombo woodlands. Pages 175-193 in B. Campbell, editor. The Miombo in transition: woodlands and welfare in Africa. Centre for International Forestry Research, Bogar, Indonesia.

Christian, C. S., and J. M. Aldrick. 1977. Alligator Rivers study: a review report of the Alligator Rivers Region factfinding study. Australian Government Publishing Service, Canberra, Australia.

Christian, C. S., and G. A. Stewart. 1953. General report on survey of the Katherine-Darwin region, 1946. CSIRO, Canberra, Australia.

Cole, M. M. 1986. The savannas: biogeography and geobotany. Academic Press, London, UK.

Cole, T. 1988. Hell west and crooked. Collins, Sydney, Australia.

Cook, G. D. 2003. Fuel dynamics, nutrients, and atmospheric chemistry. Pages 47-58 in A. N. Andersen, G. D. Cook, and R. J. Williams, editors. Fire in tropical savannas: the Kapalga experiment. Springer-Verlag, New York, New York, USA.

Cook, G. D., O. Ronce, and R. J. Williams. 1996. Suppress thy neighbour: the paradox of a successful grass that is highly flammable, but harmed by fire. Pages 71-74 in Proceedings of the 13th Fire and Forest Meteorology Conference. International Association of Wildland Fire, Lorne, Australia.

Corbett, L. 1995. Does dingo predation or buffalo competition regulate feral pig populations in the Australian wet-dry tropics? An experimental study. Wildlife Research 22:65-74.

Corbett, L., and A. L. Hertog. 1996. An experimental study of the impact of feral swamp buffalo Bubalus bubalis on the breeding habitat and nesting success of magpie geese Anseranas semipalmata in Kakadu National Park. Biological Conservation 76:277-287.

Cowie, I. D., and P. A. Werner. 1993. Alien plant species invasive in Kakadu National Park, tropical northern Australia. Biological Conservation 63:127-135.

Department of Territories. 1959. The Northern Territory Report for 1958-59. Department of Territories, Canberra, Australia.

du Toit, J., K. Rogers, and H. Biggs, editors. 2003. The Kruger experience: ecology and management of savanna heterogeneity. Island Press, Washington, D.C., USA.

East, T. J. 1990. Erosion and sediment processes in the Kakadu Conservation Zone, South Alligator River catchment, Northern Territory. AGPS, Canberra, Australia.

East, T. J. 1996. Landform evolution. Pages 37-55 in C. M. Findlayson and I. von Oertzen, editors. Landscape and vegetation ecology of the Kakadu Region, Northern Australia. Kluwer Academic Publishers, Dordrecht, The Netherlands.

Egan, D., and E. A. Howell, editors. 2001. The historical ecology handbook: a restorationist's guide to reference ecosystems. Island Press, Washington, D.C., USA.

Elliott, L. P. 2005. Spear grass in the landscape: environmental correlates of annual sarga, grass composition and fuel load in Eucalyptus miniata woodland of the greater Darwin area. Thesis. Charles Darwin University, Darwin, Australia.

Fensham, R. J., and D. M. J. S. Bowman. 1992. Stand structure and the influence of overwood on regeneration in tropical eucalypt forest on Melville Island. Australian Journal of Botany 40:335-342.
Fensham, R. J., and J. E. Holman. 1999. Temporal and spatial patterns in drought-related tree dieback in Australian savanna. Journal of Applied Ecology 36:1035-1050.

Fensham, R. J., and S. D. Skull. 1999. Before cattle: a comparative floristic study of Eucalyptus savanna grazed by macropods and cattle in north Queensland, Australia. Biotropica 31:37-47.

Finlayson, C. M., M. J. Storrs, and G. Lindner. 1997. Degradation and rehabilitation of wetlands in the Alligator Rivers Region of northern Australia. Wetlands Ecology and Management 5:19-36.

Finlayson, C. M., and I. von Oertzen, editors. 1996. Landscape and vegetation ecology of the Kakadu Region, Northern Australia. Kluwer Academic Publishers, Dordrecht, The Netherlands.

Fogarty, P. 1982. A preliminary survey of environmental damage associated with activity of feral buffalo. Technical report to the Feral Animals Committee. Conservation Commission of the Northern Territory, Darwin, Australia.

Freeland, W. J., and W. J. Boulton. 1990. Feral water buffalo (Bubalis bubalis) in the Northern Territory, Australia: population growth, minimum viable population size and the Brucellosis and Tuberculosis Eradication Campaign. Australian Wildlife Research 17:411-420.

Friend, G. R., M. L. Dudzinski, and K. M. Cellier. 1988. Rattus colletti (Rodentia: Muridae) in the Australian wet-dry tropics: seasonal habitat preferences, population dynamics, and the effects of buffalo (Bubalus bubalis). Australian Journal of Ecology 13:51-66.

Friend, G. R., and J. A. Taylor. 1984. Ground surface features attributable to feral buffalo, Bubalus bubalis II: Their relationship to the abundance of small animal species. Australian Wildlife Research 11:311-323.

Frith, H. J., and S. J. F. Davies. 1961. Ecology of the magpie goose. Wildlife Research 6:91-141.

Frost, P., E. Mediña, J. C. Menaut, O. Solbrig, M. Swift, and B. H. Walker. 1986. Responses of savannas to stress and disturbance: a proposal for a collaborative programme of research. Biology International Special Issue 10. IUBS, Paris.

Furley, P. A. 1999. The nature and diversity of neotropical savanna vegetation with particular reference to the Brazilian cerrados. Global Ecology and Biogeography 8:223-241.

Gardner, T. A. 2006. Tree-grass coexistence in the Brazilian cerrado: demographic consequences of environmental instability. Journal of Biogeography 33:448-463.

Gill, A. M., P. G. Ryan, P. H. R. Moore, and M. Gibson. 2000. Fire regimes of World Heritage Kakadu National Park, Australia. Austral Ecology 25:616-625.

Glitzenstein, J. S., W. J. Platt, and D. R. Streng. 1995. Effects of fire regime and habitat on tree dynamics in North Florida longleaf pine savannas. Ecological Monographs 65:441-476.

Graetz, R. D. 1989. Analysis of land degradation in Stage III of Kakadu National Park, including the Conservation Zone: Phase 1. Report to Australian National Parks and Wildlife Service, Canberra, Australia.

Graham, A., R. Begg, P. Graham, and S. Raskin. 1982. An aerial survey of buffalo in the Northern Territory. Conservation Commission, NT, Darwin, Australia.

Haynes, C. D. 1985. The pattern and ecology of munwag: traditional Aboriginal fire regimes in north-central Arnhemland. Proceedings of the Ecological Society of Australia 13: 203-214.

Heerdegen, R. G., and G. J. E. Hill. 1999. Freshwater to saltwater: rapid saline intrusion, East Alligator River, Kakadu National Park. Pages 144-148 in M. Roche, M. McKenna, and P. Hesp, editors. 20th New Zealand Geography Conference, New Zealand Geographical Society. New Zealand Geographical Society, New Zealand.

Higgins, S. I., W. J. Bond, and W. S. W. Trollope. 2000. Fire, resprouting and variability: a recipe for grass-tree coexistence in savanna. Journal of Ecology 88:213-229. 
Hodda, M. 1992. Ecology of termites in savanna at Kapalga, NT, Australia. Dissertation. Australian National University, Canberra, Australia.

Hopkins, B. 1992. Ecological processes at the forest-savanna boundary. Pages 21-33 in P. Furley, J. Proctor, and J. Ratter, editors. Nature and dynamics of the forest-savanna boundaries. Chapman and Hall, London, UK.

Horn, H. S. 1974. The ecology of secondary succession. Annual Review of Ecology and Systematics 5:25-37.

House, J. I., S. Archer, D. D. Breshears, and R. J. Scholes. 2003. Conundrums in mixed woody-herbaceous plant systems. Journal of Biogeography 30:1763-1777.

Huntley, B. J., and B. H. Walker. 1982. Ecology of tropical savannas. Springer-Verlag, Berlin, Germany.

Hutley, L. B., A. P. O'Grady, and D. Eamus. 2000. Evapotranspiration from Eucalypt open-forest savanna of northern Australia. Functional Ecology 14:183-194.

Jeltsch, F., G. E. Weber, and V. Grimm. 2000. Ecological buffering mechanisms in savannas: a unifying theory of longterm tree-grass coexistence. Plant Ecology 150:161-171.

Jones, R. 1980. Hunters in the Australian coastal savanna. Pages 107-146 in D. R. Harris, editor. Human ecology in savanna environments. Academic Press, London, UK.

King, J., J. B. Moutsinga, and G. Doufoulon. 1997. Conversion of anthropogenic savanna to production forest through fireprotection of the forest-savanna edge in Gabon, Central Africa. Forest Ecology and Management 94:233-247.

Knighton, A. D., C. D. Woodroffe, and K. Mills. 1992. The evolution of tidal creek networks, Mary River, northern Australia. Earth Surface Processes and Landforms 17:167190.

Lehmann, C. E. R. 2007. Tropical mesic savanna dynamics of Kakadu National Park. Ph.D. Dissertation. Charles Darwin University, Darwin, Australia.

Leichhardt, L. 1884. [Reprinted 1980]. Journal of an overland expedition in Australia, from Moreton Bay to Port Essington: a distance of upwards of 3000 miles during the years 1844-1845. Doubleday, Lane Cove, NSW, Australia.

Letts, G. A. 1964. Feral animals in the northern territory. Australian Veterinary Journal 40:84-88.

Letts, G. A., A. Bassingthwaite, and W. E. L. de Ver. 1979. Feral animals in the Northern Territory: report of the Board of Inquiry 1979. Government Printer, Darwin, Australia.

Levitus, R. 1995. Social history since colonisation. Pages 64-93 in T. Press, D. Lea, A. Webb, and A. Graham, editors. Kakadu: natural and cultural heritage and management. North Australia Research Unit, Australian National University, Darwin, Australia.

Lewis, J. 1922. Fought and won. WK Thomas Co., Adelaide, Australia.

Lockwood, D. 1979. My old mates and I. Rigby Ltd., Adelaide, Australia.

Lonsdale, W. M., and R. W. Braithwaite. 1991. Assessing the effects of fire on vegetation in tropical savannas. Australian Journal of Ecology 16:363-374.

Lucas, D., and J. Russell-Smith, editors. 1993. Traditional resources of the South Alligator floodplain: utilisation and management. Final Consultancy Report to the Australian Nature Conservation Agency, Canberra, Australia.

McKnight, T. 1976. Friendly vermin: a survey of feral livestock in Australia. University of California Press, Berkeley, California, USA.

McNaughton, S. J. 1985. Ecology of a grazing ecosystem: the Serengeti. Ecological Monographs 55:259-294.

McNaughton, S. J. 1993. Grasses and grazers, science and management. Ecological Applications 3:17-20.

Meehan, B. 1991. Wetland hunters: some reflections. Pages 197-206 in C. D. Haynes, M. G. Ridpath, and M. A. J. Williams, editors. Monsoonal Australia: landscape, ecology and man in the northern lowlands. A. A. Balkema, Rotterdam, The Netherlands.
Menaut, J. C., R. Barbault, P. Lavelle, and M. Lepage. 1985. African savannas: biological systems of humification and mineralization. Pages 14-33 in J. C. Tothill and J. J. Mott, editors. Ecology and management of the world's savannas. The Australian Academy of Science, Canberra, Australia.

Menaut, J. C., J. Gignoux, C. Prado, and J. Clobert. 1990. Tree community dynamics in a humid savanna of the Coted'Ivoire: modelling the effects of fire and competition with grass and neighbours. Journal of Biogeography 17:471-481.

Middleton, B. A., A. G. Vandervalk, R. L. Williams, D. H. Mason, and C. B. Davis. 1992. Litter decomposition in an Indian monsoonal wetland overgrown with Paspalum distichum. Wetlands 12:37-44.

Miles, G. 2003. Teetering on the edge of an answer: response to CSIRO Fire Workshop "The Kapalga Fire Experiment 1988-1994," Darwin, 27 September 2000. Pages 6-7, 11 in Savanna Links. University Press, Charles Darwin University, Darwin, Australia.

Mills, A. J., and M. V. Fey. 2005. Interactive response of herbivores, soils and vegetation to annual burning in a South African savanna. Austral Ecology 30:435-444.

Minchin, P. R., and C. R. Dunlop. 1989. Impact of feral water buffalo on savanna ecosystems in the Australian monsoon tropics. Pages 47-48 in Forests of the world: IAVS symposium. IAVS, Uppsala, Sweden.

Moreira, A. G. 2000. Effects of fire protection on savanna structure in Central Brazil. Journal of Biogeography 27: 1021-1029.

Mott, J. J., J. Williams, M. H. Andrew, and A. N. Gillison. 1985. Australian savanna ecosystems. Pages 56-82 in J. C. Tothill and J. J. Mott, editors. Ecology and management of the world's savannas. Australian Academy of Science, Canberra, Australia.

Mulvaney, J. 2004. Paddy Cahill of Oenpelli. Aboriginal Studies Press, Canberra, Australia.

Mulvaney, J., and J. Kamminga. 1999. Prehistory of Australia. Smithsonian Institution Press, Washington, D.C., USA.

Noble, J. C., and D. J. Tongway. 1986. Pastoral settlement in arid and semi arid rangelands. Pages 217-242 in J. S. Russell and R. F. Isbell, editors. Australian soils: the human impact. University of Queensland Press, Brisbane, Australia.

Northern Territory Administration Animal Industry Branch. 1961. Fifteenth annual report 1960-61 (Covering activities for year ending 30/6/61). Northern Territory Administration Animal Industry Branch, Darwin, Australia.

Northern Territory Administration Animal Industry Branch. 1962. Sixteenth annual report 1961-62 (Covering activities for year ending 30/6/62). Northern Territory Administration Animal Industry Branch, Darwin, Australia.

Northern Territory Administration Animal Industry and Agriculture Branch. 1967. Annual report 1966-67. Covering activities of the Animal Industry and Agriculture Branch for the year ending 30.6.1967. Northern Territory Administration Animal Industry and Agriculture Branch, Darwin, Australia.

Northern Territory of Australia: Office of the Government Resident. 1901. Government Resident's report on the Northern Territory, 1900. Northern Territory of Australia: Office of the Government Resident, Palmerston, Australia.

Norton-Griffiths, M. 1979. The influence of grazing, browsing, and fire on the vegetation dynamics of the Serengeti. Pages 310-352 in A. R. E. Sinclair and M. Norton-Griffiths, editors. Serengeti: dynamics of an ecosystem. University of Chicago Press, Chicago, Illinois, USA.

O'Neill, G. C., and D. V. Matthews. 1983. An investigation of recent geomorphological change on sections of the South Alligator River floodplain, Kakadu National Park. Kakadu National Park, Jabiru, NT, Australia.

Parliament of the Commonwealth of Australia. 1921. Annual report of the Acting Administrator for the year ended 30th June, 1920. The Parliament of the Commonwealth of 
Australia Northern Territory of Australia, Canberra, Australia.

Petty, A. M., and D. M. J. S. Bowman. In press. A Landsat and MODIS analysis of contrasting fire patterns in Aboriginaland park-managed lands in tropical north Australia. Journal of Fire Ecology.

Petty, A., D. Lindner, J. Freeman, and D. M. J. S. Bowman. 2005. Final report of the Kakadu National Park Channel Change Project. Department of Environment and Heritage, Canberra, Australia.

Platt, W. J., B. Beckage, R. F. Doren, and H. H. Slater. 2002. Interactions of large-scale disturbances: prior fire regimes and hurricane mortality of savanna pines. Ecology 83:15661572.

Press, T., D. Lea, A. Webb, and A. Graham, editors. 1995. Kakadu: natural and cultural heritage and management. North Australia Research Unit, Australian National University, Darwin, Australia.

Price, O., A. Edwards, G. Connors, J. Woinarski, G. Ryan, A. Turner, and J. Russell-Smith. 2005. Fire heterogeneity in Kakadu National Park, 1980-2000. Wildlife Research 32: 425-433.

Prior, L. D., B. W. Brook, R. J. Williams, P. A. Werner, C. J. A. Bradshaw, and D. M. J. S. Bowman. 2006 Environmental and allometric drivers of tree growth rates in a northern Australian savanna. Forest Ecology and Management. 234:164-180.

Prior, L. D., D. Eamus, and G. A. Duff. 1997. Seasonal and diurnal patterns of carbon assimilation, stomatal conductance and leaf water potential in Eucalyptus tetrodonta saplings in a wet-dry savanna in northern Australia. Australian Journal of Botany 45:241-258.

Ridpath, M. G. 1991. Feral mammals and their environment. Pages 169-191 in C. D. Haynes, M. G. Ridpath, and M. A. J. Williams, editors. Monsoonal Australia: landscape, ecology and man in the northern lowlands. A. A. Balkema, Rotterdam, The Netherlands.

Ridpath, M. G., R. J. Begg, M. L. Dudzinski, M. A. Fordes, and A. Graham. 1983. Counting the same populations of large tropical mammals from the ground and from the air. Australian Wildlife Research 10:487-498.

Ridpath, M. G., and J. Waithman. 1988. Controlling feral Asian water buffalo in Australia. Wildlife Society Bulletin 16: 385-390.

Riley, J. 2005. An assessment of the impact of a managed buffalo population on woody vegetation in a tropical wetland area. Thesis. Charles Darwin University, Darwin, Australia.

Robinson, C. J. 2005. Buffalo hunting and the feral frontier of Australia's Northern Territory. Social and Cultural Geography 6:885-901.

Robinson, C. J., and P. J. Whitehead. 2003. Cross-cultural management of pest animal damage: a case study of feral buffalo control in Australia's Kakadu National Park. Environmental Management 32:445-458.

Russell-Smith, J. 1984. The status and condition of monsoon vine-forests in the Kakadu region: a management report. Australian National Parks and Wildlife Service, Canberra, Australia.

Russell-Smith, J., and D. M. J. S. Bowman. 1992. Conservation of monsoon rainforest isolates in the Northern Territory, Australia. Biological Conservation 59:51-63.

Russell-Smith, J., and C. R. Dunlop. 1987. The status of monsoon vine forests in the Northern Territory: a perspective. Pages 227-288 in The rainforest legacy: Australian National Rainforest Study. Australian Government Public Service, Canberra, Australia.

Russell-Smith, J., P. G. Ryan, and R. DuRieu. 1997. A LANDSAT MSS-derived fire history of Kakadu National Park, monsoonal northern Australia, 1980-94: seasonal extent, frequency and patchiness. Journal of Applied Ecology $34: 748-766$.
Russell-Smith, J., P. J. Whitehead, G. D. Cook, and J. L. Hoare. 2003. Response of Eucalyptus-dominated savanna to frequent fires: lessons from Munmarlary, 1973-1996. Ecological Monographs 73:349-375.

San José, J. J., and M. R. Fariñas. 1983. Changes in tree density and species composition in a protected trachypogon savanna, Venezuela. Ecology 64:447-453.

San José, J. J., and M. R. Fariñas. 1991. Temporal changes in the structure of a Trachypogon savanna protected for 25 years. Acta Oecologica 12:237-247.

Sankaran, M., et al. 2005. Determinants of woody cover in African savannas. Nature 438:846-849.

Sankaran, M., J. Ratnam, and N. P. Hanan. 2004. Tree-grass coexistence in savannas revisited-insights from an examination of assumptions and mechanisms invoked in existing models. Ecology Letters 7:480-490.

Sarmiento, G. 1984. The ecology of neotropical savannas. Harvard University Press, Cambridge, Massachusetts, USA.

Schodde, R., A. B. Hedley, I. J. Mason, and P. N. Martensz. 1987. Vegetation habitats, Kakadu National Park, Alligator Rivers Region, Northern Territory. Report to Australian National Parks and Wildlife Service. CSIRO, Canberra, Australia.

Scholes, R. J., and S. R. Archer. 1997. Tree-grass interactions in savannas. Annual Review of Ecology and Systematics 28: $517-544$.

Scholes, R. J., and B. H. Walker. 1993. An African savanna: synthesis of the Nylsvley Study. Cambridge University Press, Cambridge, UK.

Sharp, B. R., and D. M. J. S. Bowman. 2004. Patterns of longterm woody vegetation change in a sandstone-plateau savanna woodland, Northern Territory, Australia. Journal of Tropical Ecology 20:1-12.

Sharp, B. R., and R. J. Whittaker. 2003. The irreversible cattledriven transformation of a seasonally flooded Australian savanna. Journal of Biogeography 30:1-20.

Sheikh, P. A., F. D. Merry, and D. G. McGrath. 2006. Water buffalo and cattle ranching in the Lower Amazon Basin: comparisons and conflicts. Agricultural Systems 87:313-330.

Silva, J. F., A. Zambrano, and M. R. Farinas. 2001. Increase in the woody component of seasonal savannas under different fire regimes in Calabozo, Venezuela. Journal of Biogeography 28:977-983.

Sinclair, A. R. E., and M. Norton-Griffiths, editors. 1979. Serengeti: dynamics of an ecosystem. University of Chicago Press, Chicago, Illinois, USA.

Skeat, A. J. 1990. Feral buffalo in Kakadu National Park: survey methods, population dynamics and control. Thesis. University of Canberra, Canberra, Australia.

Skeat, A. J., T. J. East, and L. K. Corbett. 1996. Impact of feral water buffalo. Pages 155-177 in C. M. Finlayson and I. von Oertzen, editors. Landscape and vegetation ecology of the Kakadu Region, Northern Australia. Kluwer Academic, Dordrecht, The Netherlands.

Solbrig, O. T., E. Medina, and J. F. Silva. 1996. Biodiversity and savanna ecosystem processes: a global perspective. Springer-Verlag, Berlin, Germany.

Stocker, G. C. 1972. The effects of water buffaloes on paperbark forests in the Northern Territory. Australian Forestry Research 5:29-34.

Story, R. 1976. Vegetation of the Alligator Rivers Area. Pages 89-111 in R. Story, R. W. Galloway, J. R. McAlpine, J. M. Aldrick, and M. A. J. Williams, editors. Lands of the Alligator Rivers Area, Northern Territory. CSIRO, Melbourne, Australia.

Stott, P. 1990. Stability and stress in the savanna forests of mainland south-east Asia. Journal of Biogeography 17:373383.

Suding, K. N., K. L. Gross, and G. R. Houseman. 2004. Alternative states and positive feedbacks in restoration ecology. Trends in Ecology and Evolution 19:46-53. 
Swaine, M. D., W. D. Hawthorne, and T. K. Orgle. 1992. The effects of fire exclusion on savanna vegetation at Kpong, Ghana. Biotropica 24:166-172.

Taylor, J. A., and G. R. Friend. 1984. Ground surface features attributable to feral buffalo, Bubalus bubalis I: their distribution relative to vegetation structure and plant life form. Australian Wildlife Research 11:302-309.

Tothill, J. C., and J. J. Mott, editors. 1985a. Ecology and management of the world's savannas. Australian Academy of Science, Canberra, Australia.

Tothill, J. C., and J. J. Mott. 1985b. Australian savannas and their stability under grazing. Proceedings Ecological Society of Australia 13:317-322.

Tulloch, D. G. 1968. Are buffalo a potential factor in the more rapid development of the meat industry in the north end of the NT? Northern Territory Archives NTRS 669/P1, Darwin, Australia.

Tulloch, D. G. 1969. Home range in feral water buffalo, Bubalus bubalis Lydekker. Australian Journal of Zoology 17: $143-152$.

Tulloch, D. G. 1970. Seasonal movements and distribution of the sexes in the water buffalo, Bubalus bubalis, in the Northern Territory. Australian Journal of Zoology 18:399414.

Tulloch, D. G. 1978. The water buffalo, Bubalus bubalis, in Australia: grouping and home range. Australian Wildlife Research 5:327-354.

Tulloch, D. G., and K. M. Cellier. 1986. Grazing behaviour of feral buffaloes on a native pasture in the Northern Territory Portion of the Northern Territory. Australian Wildlife Research 13:433-439.

Tulloch, D. G., and J. L. McKean. 1983. Magpie goose populations on the coastal plains of the Northern Territory (1958-1980). Corella 7:32-36.

Vandervalk, A. G., B. A. Middleton, R. L. Williams, D. H. Mason, and C. B. Davis. 1993. The biomass of an Indian monsoonal wetland before and after being overgrown with Paspalum distichum L. Vegetatio 109:81-90.

van Langevelde, F., C. van de Vijver, L. Kumar, J. van de Koppel, N. de Ridder, J. van Andel, A. K. Skidmore, J. W. Hearne, L. Stroosnijder, W. J. Bond, H. H. T. Prins, and M. Rietkerk. 2003. Effects of fire and herbivory on the stability of savanna ecosystems. Ecology 84:337-350.

van Wilgen, B. W., N. Govender, H. C. Biggs, D. Ntsala, and X. N. Funda. 2004. Response of savanna fire regimes to changing fire-management policies in a large African national park. Conservation Biology 18:1533-1540.

Walker, B. H., editor. 1987. Determinants of tropical savannas. IRL Press, Oxford, UK.

Warburton, C. 1944. Buffaloes. Angus and Robertson, Sydney, Australia.

Werner, P. A. 1986. Population dynamics and productivity of selected forest trees in Kakadu National Park. Final Report to the Australian National Parks and Wildlife Service. Australian National Parks and Wildlife Service, Canberra, ACT, Australia.

Werner, P. A., editor. 1991. Savanna ecology and management: Australian perspectives and intercontinental comparisons. Blackwell, Melbourne, Australia.
Werner, P. A. 2005. Impact of feral water buffalo and fire on growth and survival of mature savanna trees: an experimental field study in Kakadu National Park, northern Australia. Austral Ecology 30:625-647.

Werner, P. A., I. D. Cowie, and J. S. Cusack. 2006. Juvenile tree growth and demography in response to feral water buffalo in savannas of northern Australia: an experimental field study in Kakadu National Park. Australian Journal of Botany 54: $1-14$.

Werner, P. A., and P. G. Murphy. 1987. Tropical dry forests of northern Australia: population dynamics and productivity of selected forest trees. Final report to USA Man and Biosphere Program and USDA Forest Service. USDA Forest Service, Pacific Region, Honolulu, Hawaii, USA.

Werner, P. A., B. H. Walker, and P. A. Stott. 1991. Introduction: savanna ecology and management. Journal of Biogeography 17:343-345.

Westoby, M., B. Walker, and I. Noy-Meir. 1989. Opportunistic management for rangelands not at equilibrium. Journal of Range Management 42:266-274.

Williams, R. J., G. D. Cook, A. M. Gill, and P. H. R. Moore. 1999. Fire regime, fire intensity and tree survival in a tropical savanna in northern Australia. Australian Journal of Ecology 24:50-59.

Williams, R. J., A. M. Gill, and P. H. R. Moore. 1998. Seasonal changes in fire behaviour in a tropical Savanna in Northern Australia. International Journal of Wildland Fire 8:227-239.

Williams, R. J., A. D. Griffiths, and G. E. Allan. 2002. Fire regimes and biodiversity in the savannas of northern Australia. Pages 281-304 in R. A. Bradstock, J. E. Williams, and M. A. Gill, editors. Flammable Australia: the fire regimes and biodiversity of a continent. Cambridge University Press, Cambridge, UK.

Wilson, B. A., P. S. Brocklehurst, M. J. Clark, and K. J. M. Dickinson. 1991. Vegetation survey of the Northern Territory. Technical Report No. 49. Conservation Commission of the Northern Territory, Darwin, Australia.

Wilson, B. A., J. Russell-Smith, and R. F. Williams. 1996. Terrestrial vegetation. Pages 57-79 in C. M. Finlayson and I. von Oertzen, editors. Landscape and vegetation ecology of the Kakadu Region, Northern Australia. Kluwer Academic, Dordrecht, The Netherlands.

Winter, W. H. 1991. Australia's northern savannas: a time for change in management philosophy. Pages 181-186 in P. A. Werner, editor. Savanna ecology and management: Australian perspectives and intercontinental comparisons. Blackwell Scientific Publications, London, UK.

Woinarski, J. C. Z., D. J. Milne, and G. Wanganeen. 2001. Changes in mammal populations in relatively intact landscapes of Kakadu National Park, Northern Territory, Australia. Austral Ecology 26:360-370.

Woinarski, J. C. Z., J. Risler, and L. Kean. 2004. Response of vegetation and vertebrate fauna to 23 years of fire exclusion in a tropical Eucalyptus open forest, Northern Territory, Australia. Austral Ecology 29:156-176.

Woodroffe, C. D., B. G. Thorn, and J. Chappell. 1985. Development of widespread mangrove swamps in midHolocene times in northern Australia. Nature 317:711-713. 